\title{
Research Paper \\ The Comparison of the Effectiveness of Cognitive Behavioral Therapy and Metacognitive Therapy on Depression, Suicide Ideation, and Masochistic Aggression in Individuals with Subclinical Symptoms of Body Dysmorphic Disorder
}

\author{
Somaye Entezari ${ }^{1}$, Mahboobe Taher ${ }^{* 2}$, Hakime Aghaei ${ }^{2}$ \\ 1. Ph.D. Student of Psychology, Department of Psychology, Shahrood Branch, Islamic Azad University, Shahrood, Iran \\ 2. Assistant Professor, Department of Psychology, Shahrood Branch, Islamic Azad University, Shahrood, Iran
}

Citation: Entezari S, Taher M, Aghaei H. The comparison of the effectiveness of cognitive behavioral therapy and metacognitive therapy on depression, suicide ideation, and masochistic aggression in individuals with subclinical symptoms of body dysmorphic disorder. J Child Ment Health. 2021; 7(4): 1-18.

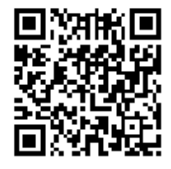

URL: http://childmentalhealth.ir/article-1-1069-en.html

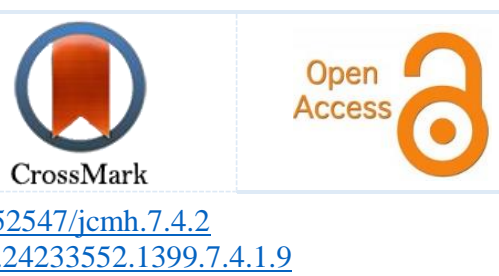

A R T I C L E I N F O

Keywords:

Cognitive behavior

therapy,

metacognitive therapy,

body dysmorphic

disorder,

depression,

suicide ideation,

masochistic aggression

Received: 9 Sep 2020

Accepted: 11 Dec 2020

Available: 28 Feb 2021

\section{A B S T R A C T}

Background and Purpose: The most common comorbid disorder with body dysmorphic disorder (BDD) is depression. Masochistic aggression and suicide are the main concerns about individuals with BDD who suffer from depression and have impaired function. Present study aimed to compare the effectiveness of cognitive behavioral therapy (CBT) and metacognitive therapy (MCT) on depression, suicide ideation, and masochistic aggression among individuals with subclinical symptoms of BDD.

Method: This study was a quasi-experimental study with a control group pretest-posttest design. The sample included 51 girls with subclinical symptoms of BDD who had been selected with purposive sampling from a public secondary school in Tehran in the academic year 2018-2019. After being evaluated and giving the informed consent, the participants were randomly assigned to one of the two experimental groups of CBT and MCT or waiting list. The participants completed the Body Image Concern Inventory (Littleton, 2005), Beck Depression Inventory-II (Beck et al., 1996), Beck Scale for Suicide Ideation (Beck et al., 1979), and masochistic aggression subscale of Aggression Styles Inventory (Alavizadeh \& et al., 2016) at the pre-test, post-test and 3 months follow-up stages. Data were analyzed by repeated-measures ANOVA in SPSS- 26.

Results: Results showed that although CBT and MCT were effective in alleviating the symptoms of depression $(\mathrm{p}<0.01)$, suicide ideation $(\mathrm{p}<0.01)$ and masochistic aggression $(\mathrm{P}<0.05)$, CBT was more effective in decreasing depression $(\mathrm{p}<0.05)$. There was no significant difference between CBT and MCT in terms of their effect on suicide ideation and masochistic aggression $(\mathrm{P}<0.05)$.

Conclusion: According to these findings, it can be concluded that CBT and MCT are effective in alleviating the mood-related symptoms in individuals with subclinical symptoms of BDD. Furthermore, the behavioral activation session can be the reason of the higher effectiveness of CBT.

* Corresponding author: Mahboobe Taher, Assistant Professor, Department of Psychology, Shahrood Branch, Islamic Azad University, Shahrood, Iran.

E-mail: Mahboobe.taher.com

Tel: (+98) 2332394530

2476-5740/ (C) 2021 The Authors. This is an open access article under the CC BY-NC-ND license

(https://creativecommons.org/licenses/by-nc-nd/4.0/). 


\section{Extended Abstract}

\section{Introduction}

Body dysmorphic disorder (BDD) is a mental disorder determined by a severe or slight defect in individual appearance perception (1). BDD is a debilitating disorder that is associated with severe social dysfunction (2). BDD has a relatively high prevalence in the general population by a 12 -month prevalence rate of $1.8 \%$ (3). Depression is the most common comorbid disorder with BDD (4). The individuals with BDD describe it as their biggest issue (5). These signs and symptoms develop after the onset of BDD (6). It is also predictable that depression will improve if BDD is treated effectively.In the case-conceptualization of persons with BDD, signs, and symptoms of depression lead to the diagnosis of depressive disorder. The most important concern for individuals with BDD who are depressed and have impaired function is suicide (2). People with BDD have a relatively higher suicide rate than clients with obsessive-compulsive disorder (4). In particular, clients who blame themselves for their face may be at risk; other high-risk people are those who have high expectations of surgery and feel frustrated after a failure because they believe there would be no other solutions (5). In initial studies (6) a high rate of suicide attempts was founded among individuals with BDD.

There are several treatments for mental disorders. Cognitive-behavioral therapy (CBT) is an empiricallysupported treatment for many psychological disorders (15-22). Metacognitive therapy (MCT) $(16,26-31)$ is developed based on the metacognition principle that is very important for understanding how cognition works and how we produce conscious experiences.

As there was no study to compare these two interventions in adolescents with subclinical BDD, present study aimed to compare the CBT and MCT and determine their effectiveness on depression, suicide-ideation (SI), and masochistic aggression (MA) among adolescent girl students with subclinical BDD in Tehran.

\section{Method}

Present study is a quasi-experimental study with a pretest-posttest design with two experimental groups and a control group. The population of this study included the 16-18-year-old high school girls with subclinical BDD in the city of Tehran in the academic year 2018-2019. The sample was including 51 individuals from this population who had been selected by convenience and purposive sampling methods based on the inclusion and exclusion criteria. The inclusion criteria contained: a score less than 67 in the body image concern inventory and the age range of 16 to 18 ; while the exclusion criteria included having any mental disorder, according to the individual reports, and undergoing concurrent psychiatric treatment or psychotherapy. After obtaining the informed consent from them and their parents, the participants entered into the randomization stage. The participants were randomly assigned to one of the two experimental groups receiving MCT or CBT, or the wait list control group (17 per group). The participants completed the Persian forms of the Body Image Concern Inventory (BICI) (41), Beck Depression Inventory-2 (43), Beck Scale for Suicidal Ideation (46), and masochistic aggression subscale of Aggression Styles Inventory (Alavizadeh, Entezari, Mami, 2016; quoted by (13)), in the pretest, post-test, and 3 months follow-up stages. The participants in the experimental groups received ten 90-minute treatment sessions in 5 weeks (two sessions per week). The first experimental group received CBT (6) for 10 sessions and the second experimental group received MCT (26) for 10 sessions. Data were analyzed by repeated measure analysis of variance in SPSS-26.

\section{Results}

In this study, data were analyzed based on the within factor, which means the time of measuring variables, and the between factor or membership in study groups. After considering the assumptions for repeated measure the findings showed that the data have a normal distribution, the pre-test variances of the dependent variables between the experimental and control groups had not been significantly different, and the Kolmogorov-Smirnov test and the Leven's homogeneity of variances test also were not significant ( $>00.05$ ), therefore, the pre-conditions for performing statistical analyzes are met. 
Table 1-Eng: Inferential descriptive results of dependent variables in the pre-test, post-test, and 3-month follow-up phases

\begin{tabular}{|c|c|c|c|c|c|c|c|c|c|}
\hline variable & Stage & & & & & & Scheffe & pairwise co & parison \\
\hline \multirow{4}{*}{ Depression } & & $\mathbf{W L}$ & CBT & MCT & $\mathbf{F}$ & $\mathbf{p}$ & CBT-MCT & CBT-WL & MCT-WL \\
\hline & Pretest & $15.71(2.93)$ & $14.35(4.53)$ & $14.94(6.90)$ & 0.31 & 0.74 & 0.74 & 0.44 & 0.67 \\
\hline & post-test & $15.29(3.02)$ & $6.24(2.80)$ & $10.64(4.60)$ & - & - & - & - & - \\
\hline & follow-up & $15.29(3.27)$ & $5.94(2.30)$ & $10.18(4.13)$ & 13.97 & 0.01 & 0.05 & 0.01 & 0.05 \\
\hline \multirow{3}{*}{ SI } & Pretest & $14.18(5.38)$ & $12.17(5.28)$ & $15.88(4.28)$ & 1.72 & 0.20 & 0.07 & 0.40 & 0.33 \\
\hline & post-test & $14.06(5.67)$ & $8.82(3.41)$ & $10.12(2.55)$ & - & - & - & - & - \\
\hline & follow-up & $14.00(5.61)$ & $8.76(3.68)$ & $10.24(2.51)$ & 3.64 & 0.04 & 0.56 & 0.03 & 0.05 \\
\hline \multirow{3}{*}{ MA } & Pretest & $2.18(1.42)$ & $1.94(1.25)$ & $2.12(1.36)$ & 0.14 & 0.87 & 0.71 & 0.62 & 0.90 \\
\hline & post-test & $1.88(1.41)$ & $1.06(0.75)$ & $1.35(0.93)$ & - & - & - & - & - \\
\hline & follow-up & $2.24(1.30)$ & $0.65(0.45)$ & $1.06(0.83)$ & 3.31 & 0.05 & 0.99 & 0.05 & 0.04 \\
\hline
\end{tabular}

Table 1-Eng shows the mean and standard deviation of the dependent variables at different stages of measurement. As can be seen in the pre-test rows of three variables, at the pre-test stage, there was no significant difference between the groups in terms of the study variables; i.e. depression $(\mathrm{F}=0.31$, $\mathrm{p}=0.74)$, SI $(\mathrm{F}=1.72, \mathrm{p}=0.20)$, and MA $(\mathrm{F}=0.14$, $\mathrm{p}=0.87)$. This finding shows that random assignment did not make a difference between the groups at the beginning. In addition, the results of repeated measures analysis of variance are visible in the follow-up phase. Results of analysis of generalized linear models indicated that there were significant differences between the studied groups in depression $\left(\mathrm{F}=13.97, \mathrm{p}<0.01, \eta^{2}=0.37\right)$, SI $(\mathrm{F}=3.64, \mathrm{p}<0.04$, $\left.\eta^{2}=0.13\right)$, and MA $\left(F=3.31, p<0.5, \eta^{2}=0.12\right)$. The results of Scheffe's pairwise comparison showed that CBT was more effective on the depression variable than MCT $(\mathrm{p}<0.05)$ in the follow-up phase, although both treatments were considered effective with regards to the control group $(\mathrm{p}<0.05)$.

\section{Conclusion}

The present study aimed to compare the effectiveness of CBT and MCT on depression, SI, and MA among individuals with subclinical BDD. The results demonstrated that both treatments were effective in all dependent variables $(16,17,27-31)$. In all of these studies, CBT and MCT were effective in reducing depression. Furthermore, CBT was more effective than MCT in reducing depression. The behavioral activation (BA) session in the CBT-protocol may be the reason for this superiority. Regarding the second and third hypotheses of this study based on comparing the effectiveness of CBT and MCT on SI and MA in persons with subclinical symptoms of BDD, there was no difference between the two interventions; both were effective. This finding is supported by Ghasemi et al., (2017), Perry-Parrish et al., (2016), Hopwood et al., (2017) quoted by Hamidi, Shariat, Aghabzorgi, Keshavarz Mohammadi (21).

This study also had some limitations. First, subclinical symptoms of BDD can be considered as a normal developmental process; second, subclinical symptoms in this study were calculated only based on the cut-point of the BICI; and third limitation is the implementation of both treatments by the same researcher, which can lead to bias. It is suggested that in the next studies, the subclinical symptoms of BDD can be assessed in addition to the cut-point of BICI based on structured clinical interviews. Moreover, the effectiveness of these interventions in other developmental groups and in individuals treated by therapists different from the researchers themselves can be compared. Finally, therapists are advised to use BA components in their treatment of clients with depressive symptoms. 


\section{Ethical Considerations}

Compliance with ethical guidelines

This article is extracted from the Ph.D. dissertation of the first author, which was approved in Psychology Department, Shahrood Branch, Islamic Azad University with the number 162280151, on 27.01.2019 and successfully defended on 01.10.2020. The informed consent of the participants and their parents also were received in this study.

Funding: This study was conducted without the financial support of any public or private institution or organization.
Authors' contribution: This article is extracted from the Ph.D. dissertation of the first author and under the supervision of the second and third authors.

Conflict of interest: The authors also declare that there is no conflict of interest in the results of this study.

Acknowledgments: We would like to thank the participants in this study and the officials of the education department at District 10 of Tehran who made this research possible. 


\section{مقايسه اثربخشى درمانهاى شناختى -رفتارى و فراشناختى بر افسردكى، انديشه يردازى خود كشى، و يرخاشكرى

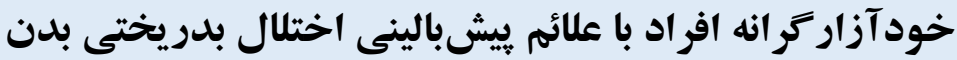

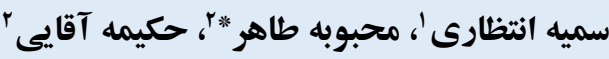

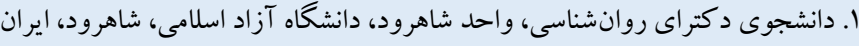

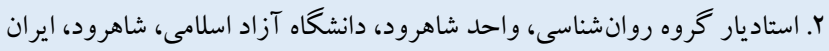

\section{جكيده}

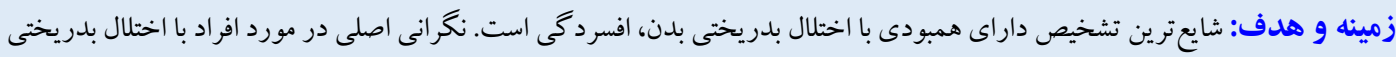

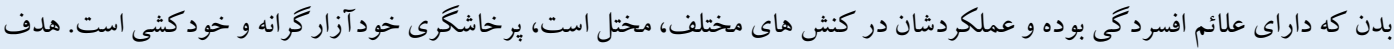

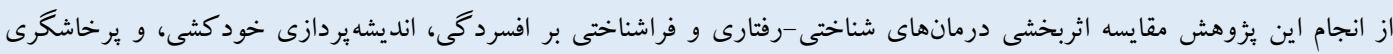

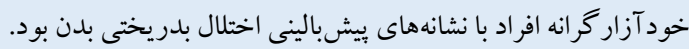

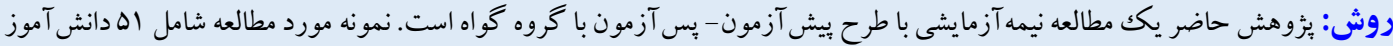

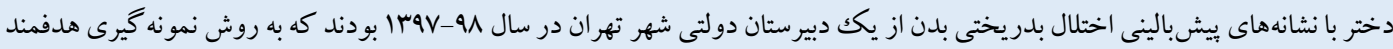

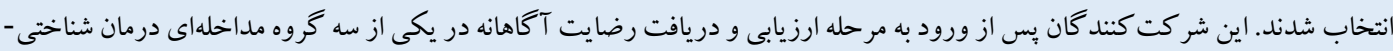

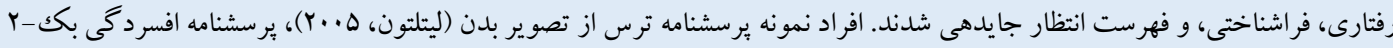

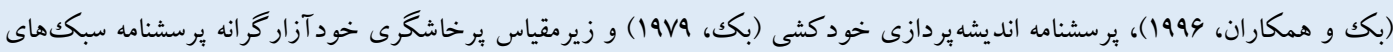

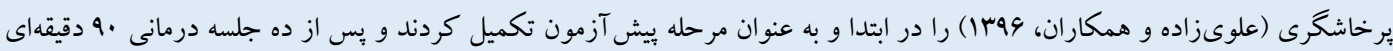

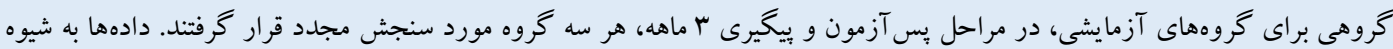

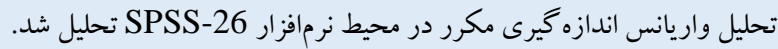

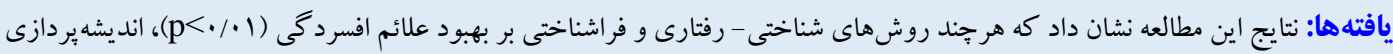

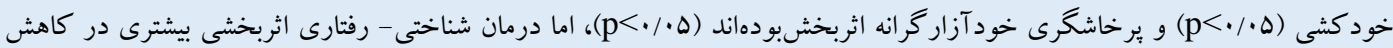

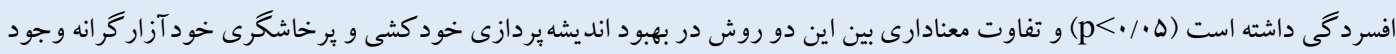

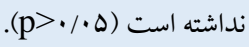

نتيجه كيرى: بر اساس اين يافتها مىتوان بيان كرد كه هر دو روشهاى شناختى- رفتارى و فراشناختى بر بهبود نشانههاى مر تبط با خلق

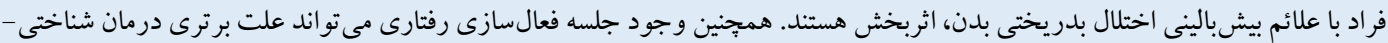

مشخصات مقاله

كليدواثهها:

دومان رفتارى- شناختى و

فراشناختى،

اختلال بدريختى بدن،

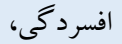

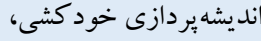

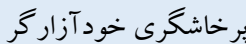

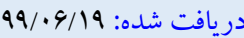

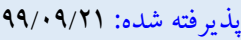
$99 / 1 Y / 1 \cdot$ منتشر شده

* نويسنده مسئول: محبوبه طاهر، استاديار گروه روانشناسى، واحد شاهرود، دانشكاه آزاد اسلامى، شاهرود، ايران.

Mahboobe.taher.com رايانه

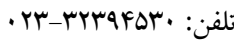




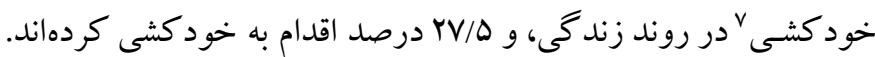

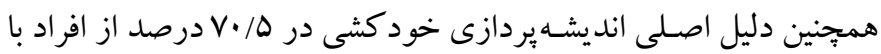

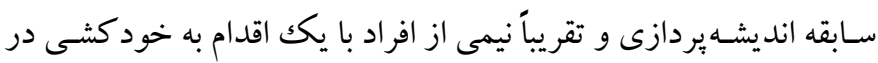

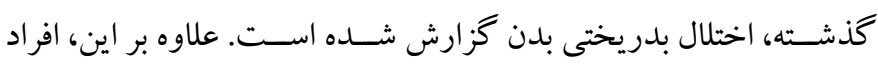
اقـدام كنــــه بـه خود كشـى اغلب علائم اختلال بدريختى بدن خود را به

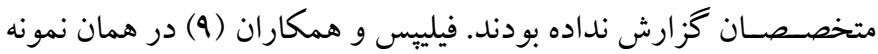

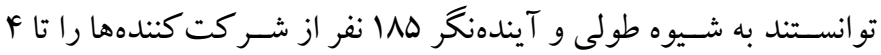

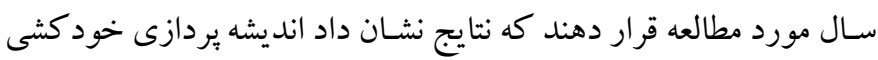

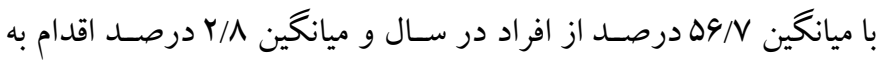

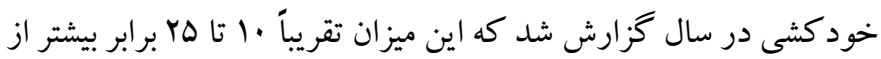

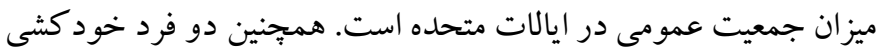
كردند (攵 درصد در سال) كه F تا سا برابر بيشتر از ميزان خود كشى در جمعيت عمومى آمريكا اســت. هر جند اين نتايج اوليه اســت، اما نشـــان مىدهد كه خود كشى در افراد با اختلال بدريختى بدن بسيار زياد اسـت.

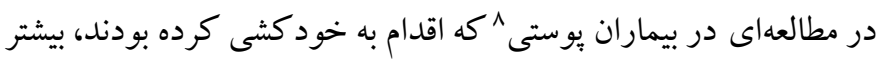

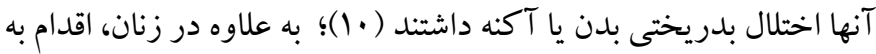
خود كشى به شكل معنادارى با خود آزار گرى هُ ارتباط داشته است (11).

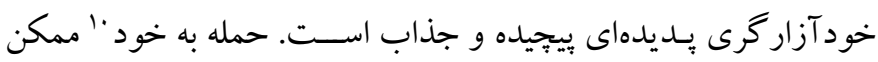

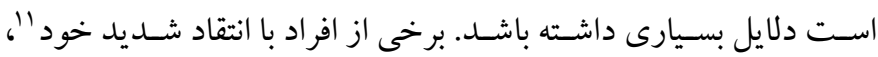

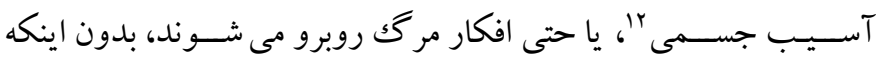

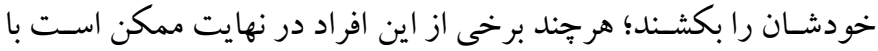

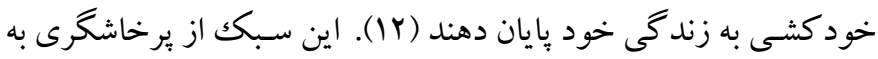

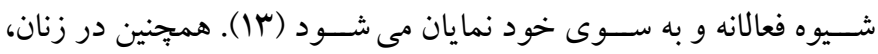

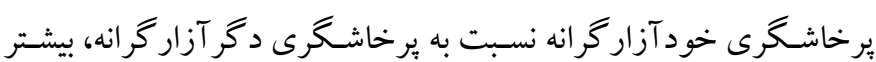

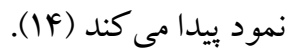

درمانهاى مختلفى براى اختلالهاى روانشناختى وجود دارد. درمان

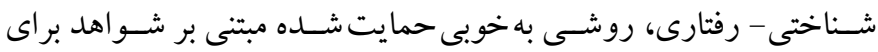

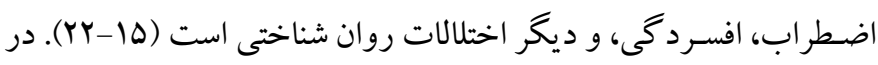

\section{Suicide ideation}

8. Dermatologic patients

9. Masochism

10. Self-attack

11. Harsh self-criticism

12. Bodily harm
مقدمه

اختلال بدريختى بدن'، اختلالى روانى است كه با دلهرهاى شديد و آشكار

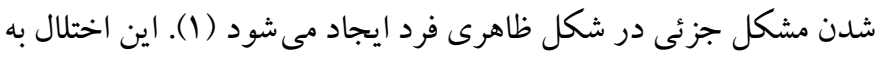

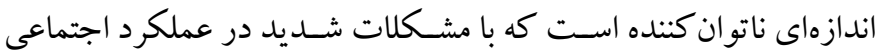
همراه اسـت (Y) و با ميزان شيوع ^/ا د درصد در جمعيت عمومى، فراوانى

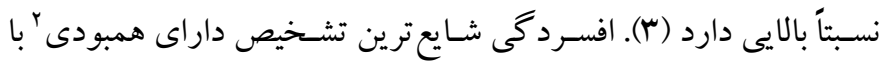

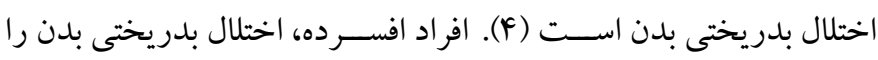

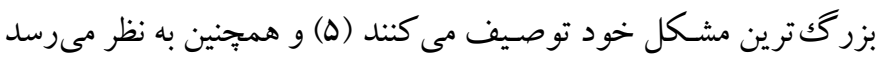

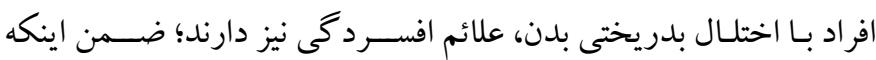
علائم افسـردگى يس از شـروع اختلال بدريختى بدن ايجاد مى شـود (9).

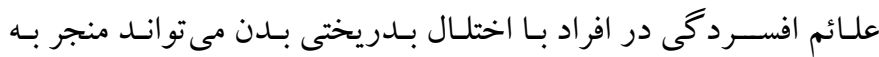

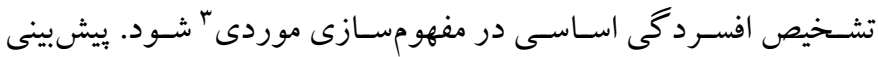

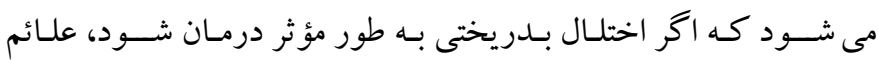

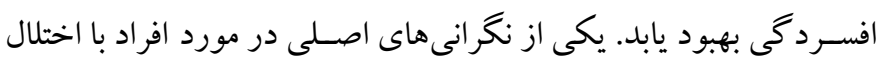

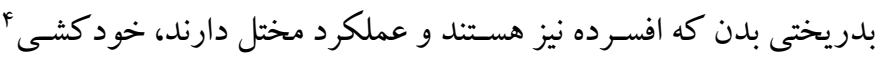

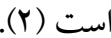

افر اد با اختلال بدريختى بدن در مقايسه با مراجعان با اختلال وسواسى

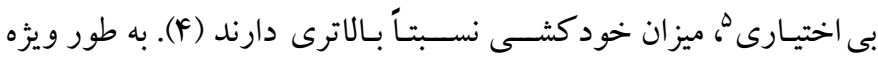
مر اجعانى كه خود را به خاطر ظاهر خود سـرزنش مي كنتن، ممكن اسـت

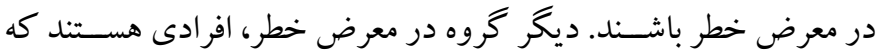

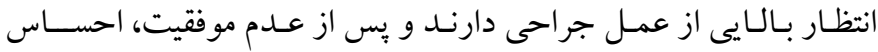

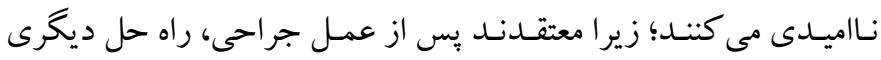
وجود ندارد (ه). در بررسى هاى اوليه ميزان بالاى تلاش براى خود كشى بهى

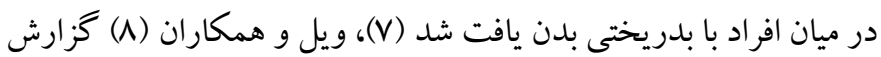

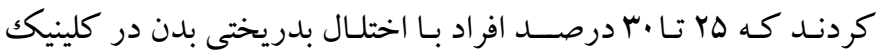
روانيزشـكى، سـابقه اقدام به خود كشـى داشـتهاند. در بزركَ ترين نمونه

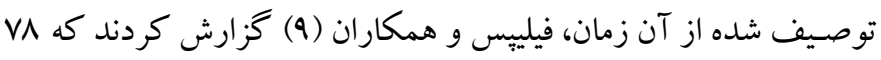
درصد از نمونه ..r نفرى از افراد با اختلال بدريختى بدن با انديشهيردازى

1. Body dysmorphic disorder

2. Comorbidity

3. Case conceptualization

4. Suicide

5. Obsessive compulsive disorder

6. Suicide attempt 


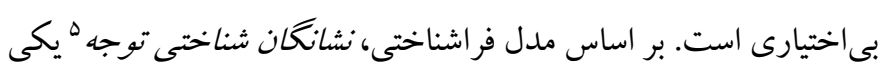

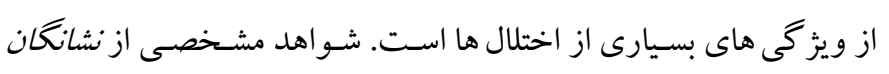

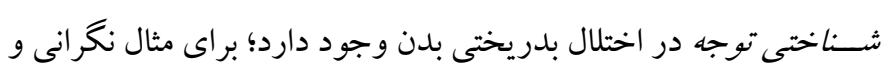

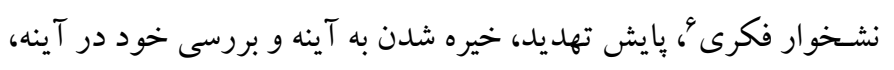

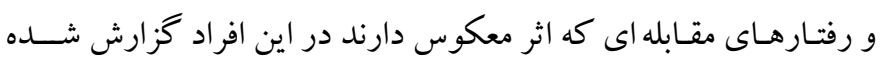

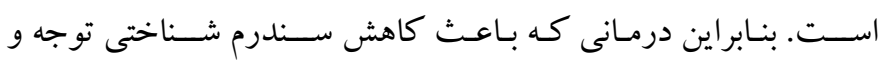

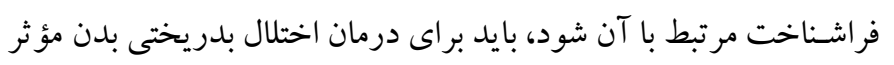

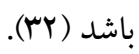

تا كنون هيج كار آزمائى تصادفى به عنو ان مداخله روان شناختى براى

كاهش علائم خلقى در كود كان و نوجو انان با نشانه هاى بيش بـ بالينى اختلال بلدريختى بدن وجود نداشته است. يكك گز ارش موفقيت آميز رفتاردرمانى

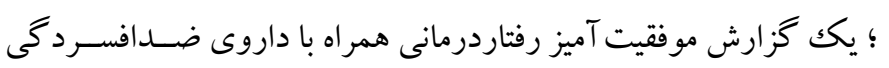

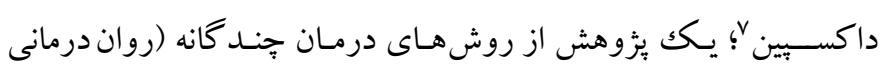

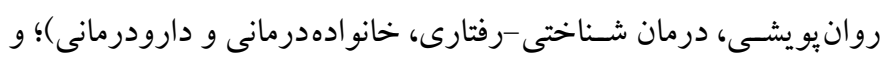

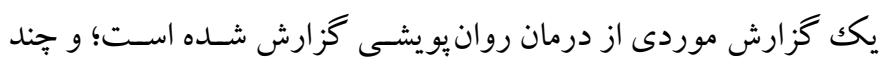

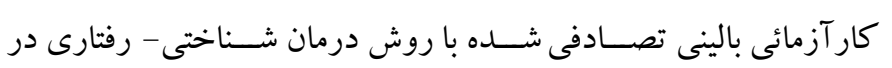
بزر گسالان با اختلال بدريختى بدن انجام شده است (به نقل از و و). همجينين

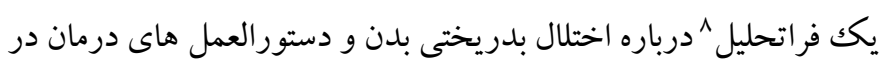

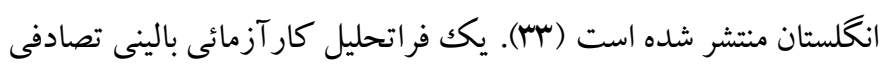

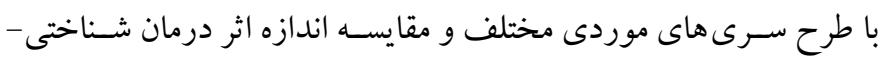

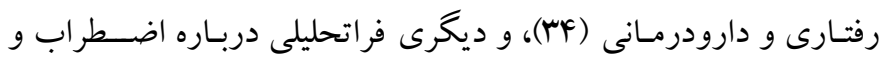

$$
\text { افسرد گى (ه) نيز منتشر شده است. }
$$

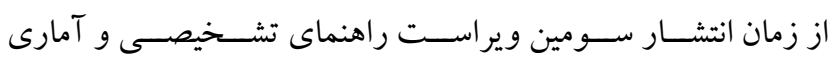

اختلالهاى روانى در سـال •و191، دقت تشـخيصى اين نظام طبقهبندى با

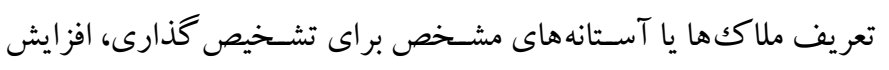

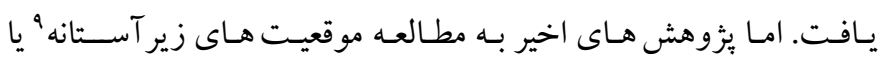

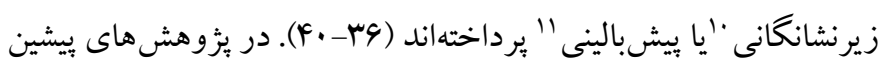

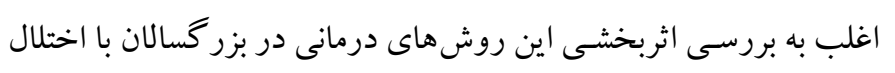

\section{Doxepin}

8. Meta-analysis

9. Subthreshold

10. Subsyndromal

11. Subclinical
سـال هاى كذشـته درمان شناختى - رفتارى، روش درمانى بيشنهادى براى

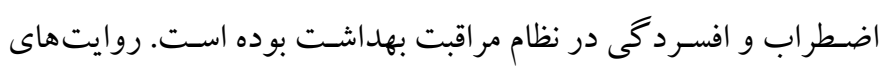

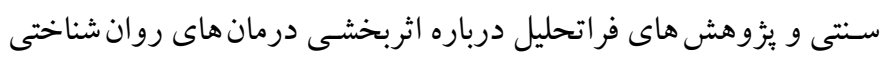

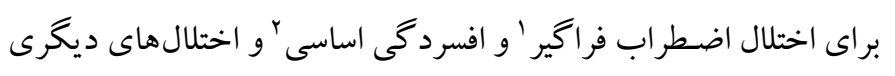

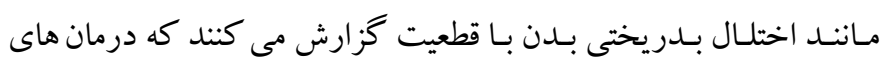

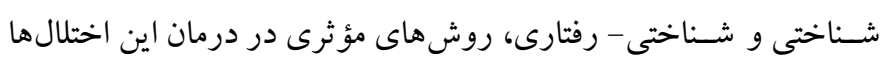

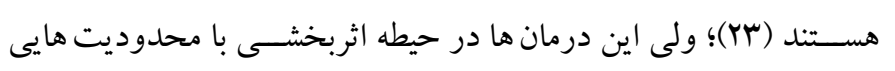
مواجه هستند (YF). (MF)

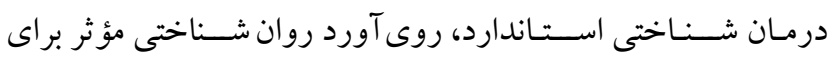

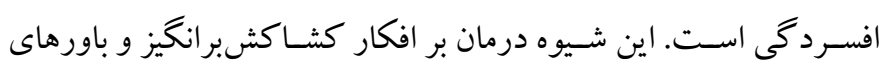

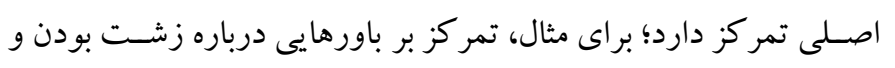

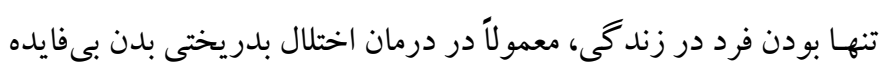

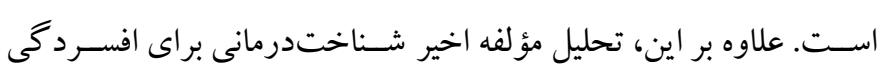

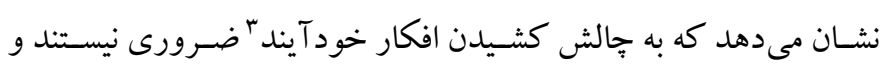

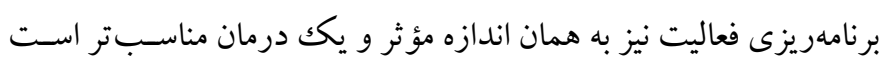

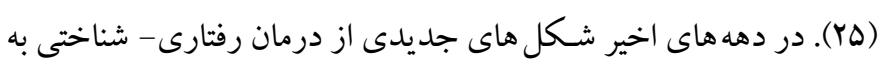

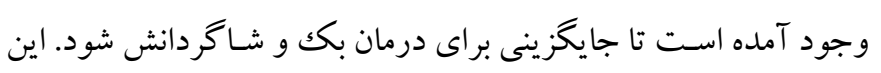

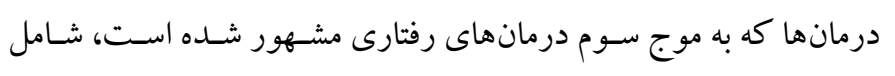

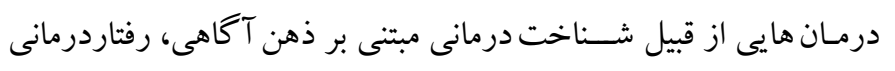

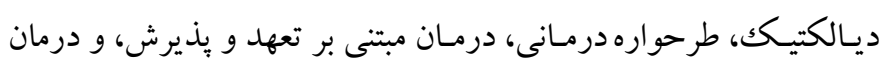

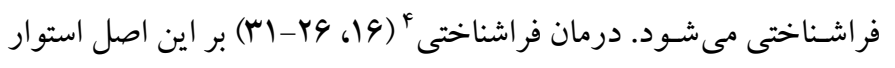

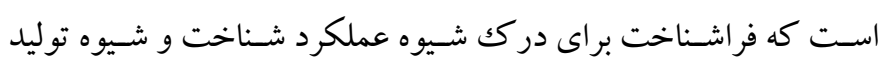

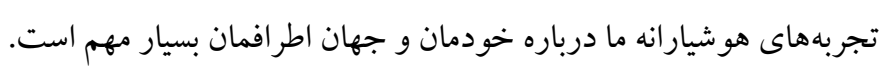

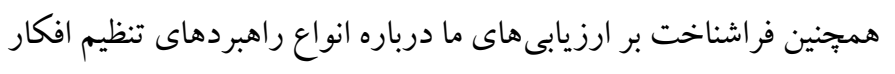

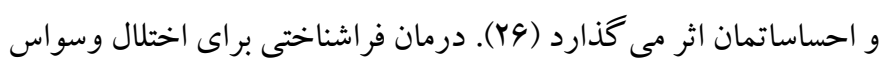

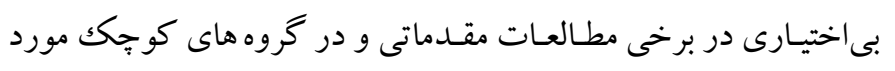

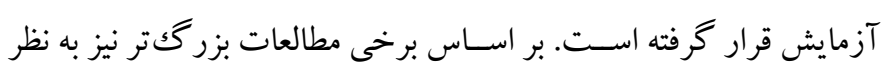

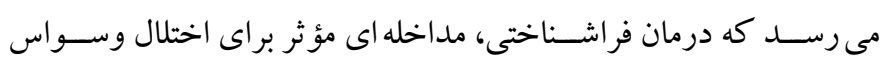

1. Generalized anxiety disorder

2. Major depressive disorder

3. Automatic thought

4. Metacognitive therapy (MCT)

5. Cognitive attentional syndrome

6. Rumination 
والـدينشــان، بـه طور تصــادفى و بـهـ تعـداد برابر در يكى از دو كروه آزمايشى دريافت درمان فراشناختى و درمان شناختى - رفتارى، و كروه

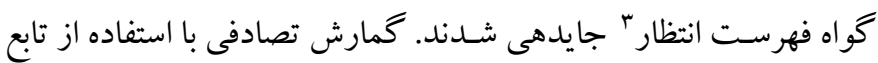

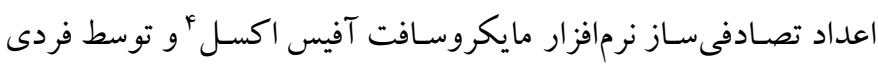

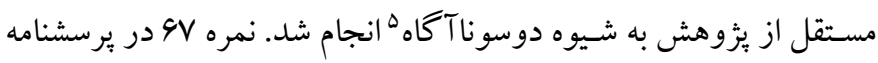

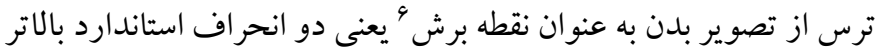

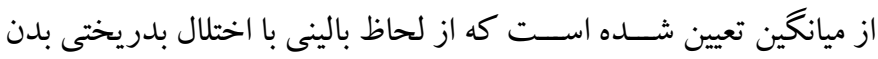

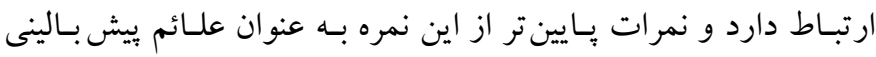

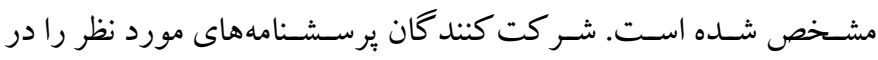

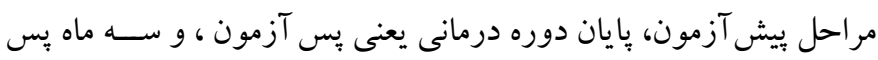

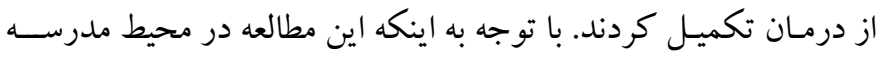

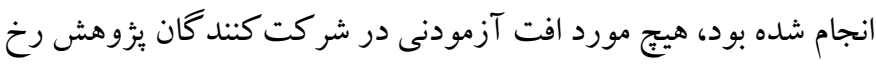

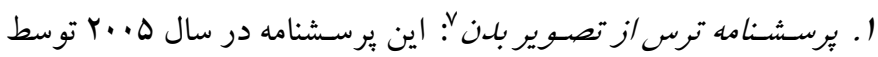

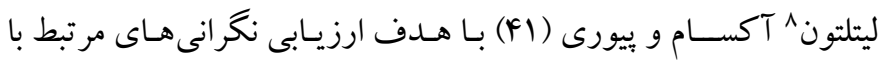

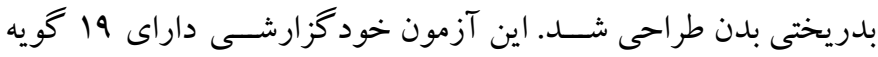

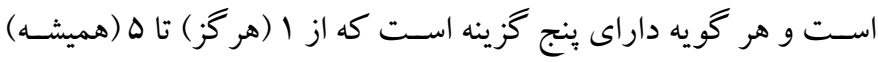

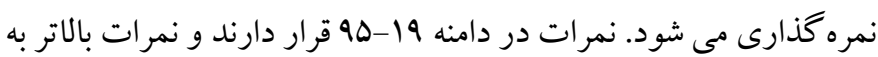

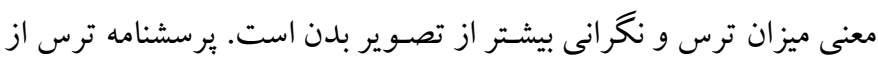

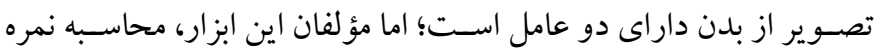

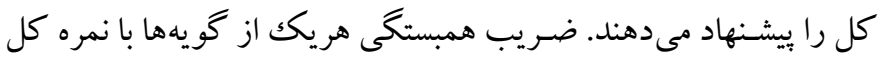

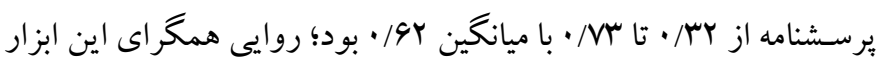

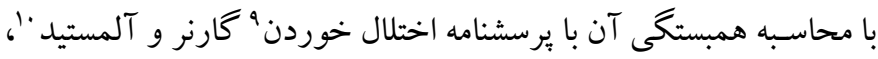

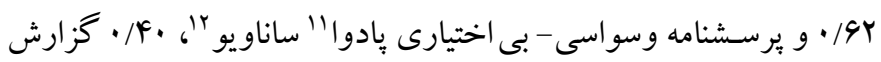

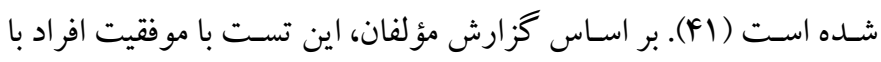

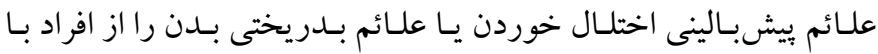

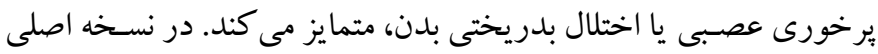

\section{Littleton}

9. Drive for Thinness subscales of the Eating Disorder Inventory (EDI)

10. Garner and Olmstead

11. Obsessions and compulsions: The Padua inventory

12. Sanavio
بدريختى بدن يرداخته شـــه اســت و يزووهش هاى اندكى در كود كان و

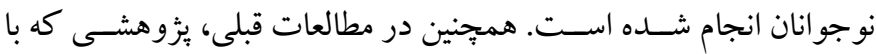

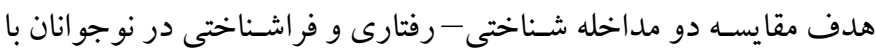
علائم بيش بالينى اختلال بدريختى بدن انجام شده باشد، يافت نشده است؛ بر اين اسـاس، اين يزوهش با هدف مقايسه و تعيين اثربخشى درمانهاى

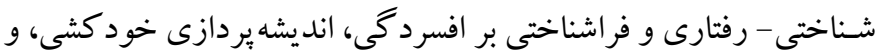

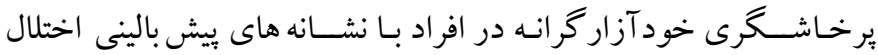
بدريختى بدن اجرا شد.

روش الف) طرح هزوهش و شـــ كت كنند كان: اين يزوهش از نوع مطالعات

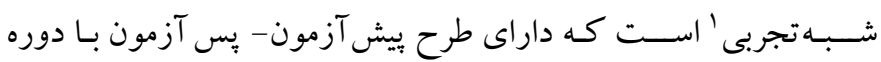

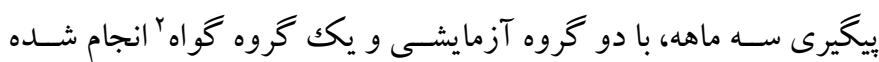

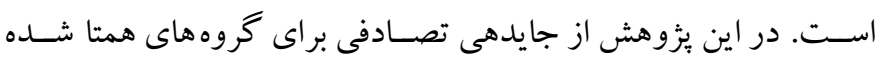

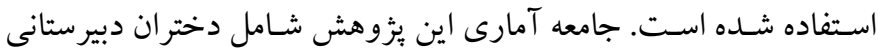
19-19 سـاله شـهـر تهر ان بود كه داراى نشــانه هاى بيش بالينى اختلال بــدريختى بـدن بودنــ. در يثزوهش هاى مداخلهاى به طور معمول حداقل

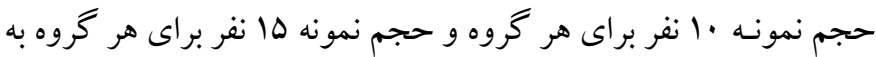
عنوان حد كفايت حجم نمونه بيشنهاد شده است؛ اما با توجه به بيشبينى

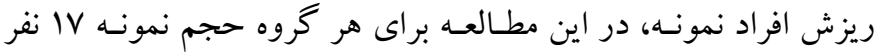

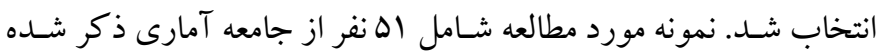
بود كه به صسورت هدفمند و در دسـترس بر اسـاس ملاككهاى ورود و

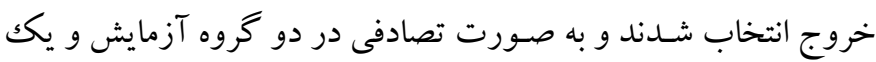

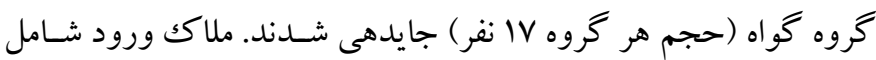
نمره كمتر از 9V در برسشنامه ترس از تصوير بدن و دامنه سنى 19 تا ل1؟؛

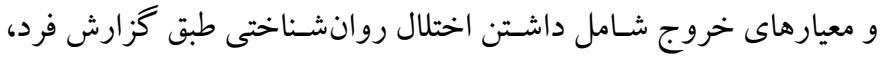
دريافت درمان روانيزشــكى يا رواندرمانى همزمان، و غيبت بيش از دو

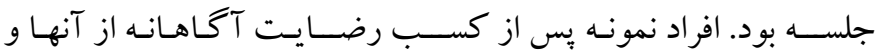

1. Quasi-experimental study

2. Pretest-posttest control group design

3. Waiting list control group

4. Microsoft Office Excel random number generator

5. Double-blind

6. Cut-point

7. Body Image Concern Inventory (BICI) 
يرسـشـامه به معنى افكار خود كشى گر ايانه بيشـتر است. در مطالعه اصلى

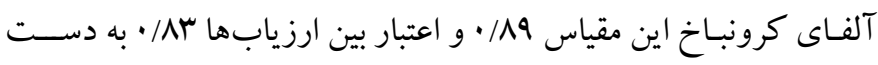
آمـده اســت. همجينين روايى همز مـان آزمون بـا مقيـاس ســنجش خطر خود كشىى، 199/ • كزارش شده است. مطالعات، تأييد كننده روايى محتوا و اعتبار نسبى نسـخه فارسى اين برسـشـنامه در جمعيت ايرانى اسـت؛ به

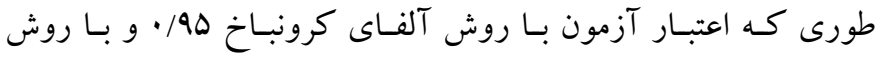
دونيمهسازى VD/ •؛ و روايى همزمان آن از طريق محاسبه همبستخى آن با

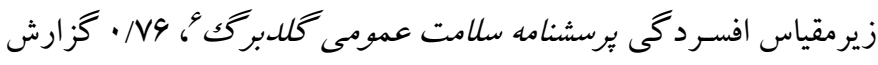

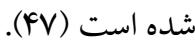

F. مقياس سـبكك هاى برخاشـكرى v: اين مقياس كه توســط علوىزاده، انتظارى، مامى (19 (Y) نقل از (r) طراحى شـده اسـت داراى •و كويه اســت كـه هر كدام به شــكل بلى يا خير ياســـخ داده مى شـــود. مقياس سـبك هاى يرخاشـكرى از جهار زيرمقياس دگر آزارگر ^(بيرونى فعال)،

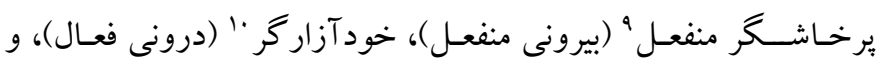

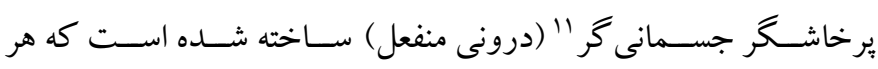
زيرمقيـاس ها كويـه دارد و نمرات هر زيرمقيـاس بين · تـا ها اســت و نمرات بالاتر نشـاندهنده شـدت برخاشـكرى در آن سـبك يرخاشـرى است. نتايج نشان داد كه اين يرسشنامه از همسانى درونى خوبى برخوردار اســت كـه بـه روش آلفـاى كرونبـاخ براى زيرمقيـاسهـاى دكر آزاركر

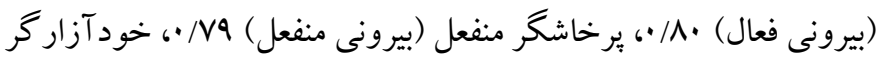

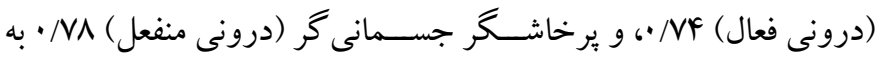
دسـت آمد. مدل جهار عاملى اين برســـامه نيز تأييد شده است. ضريب يايايى اين برســـــنامه به فاصـله دو هفته براى كل آزمون MM/ • و براى

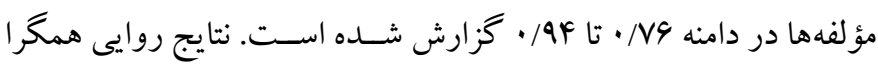

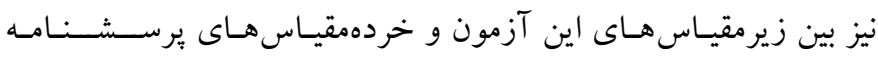

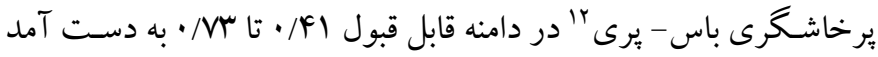

7. Aggression styles Inventory

8. Sadistic aggression

9. Passive aggression

10. Masochistic aggression

11. Somatic aggression

12. Buss-Perry Aggression Questionnaire
اين برسـشـنامه همسـانى درونى' به روش آلفاى كرونباخ، سه/ • گزارش شـده اسـت ( (F). در ئزوهشى در ايران اعتبار اين آزمون با ضريب آلفاى

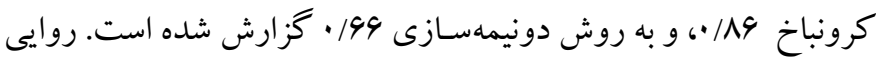
سـازه اين يرسـشــامه نيز دو عاملى بودن يرسـشــامه را با ضـريب تبيين M/M (AY ) • بوده است (FY).

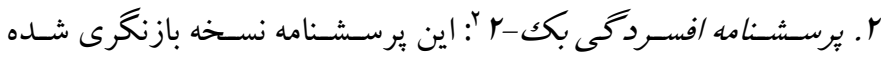
يرسـشـنامه افسـردگى بك اسـت و با ملاكك هاى افسردكى در جهارمين ويراسـت راهنماى تشخيصى و آمارى اختلالات روانى منطبق شده است (FT). اين ابزار همانند نسخه اول برسشنامه افسردگى بكك، ال كويه دارد

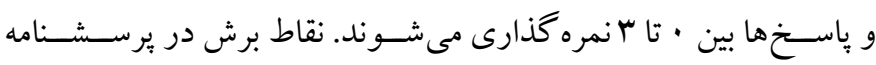
افسـردگى بكك-r با برسـشـنامه افسردگى بك تفاوت دارد؛ به طورى كه

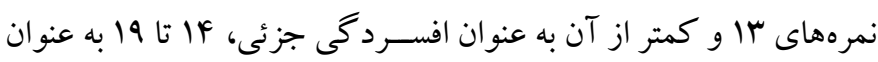

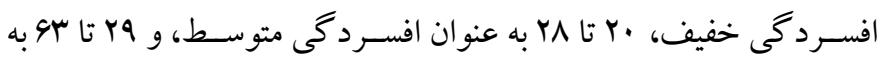
عنوان افسردگى شـديد مشـخص شدهاند. در نتيجه كسب نمرههاى بالاتر در اين يرسشنامه نشاندهنده نشانهاى افسردگى شديدتر است (هA). اين

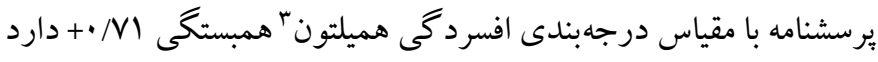
و يـايـايى باز آزمايى يكك هفتهاى آن به/ • اســـ؛ همســانى درونى اين

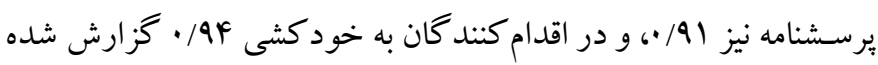
اسـت (FF). در ايران دابسون و محمدخانى (FA)، ضريب آلفاى كرونباخ

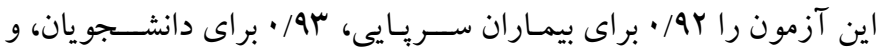
ضـريب باز آزمايى آن را سه/ • گزارش كردند. همجينين روايى سـازه بر

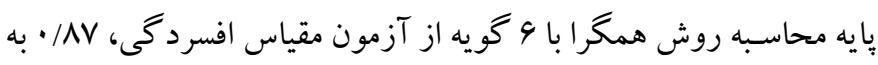
دست Tمد.

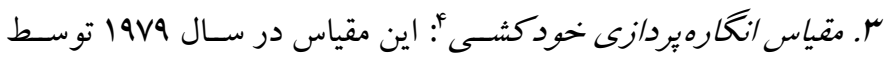
بكك و همكاران طراحى شـد (F4) كه حاوى 19 كويه اسـت و هر گويه داراى سـه گزينه اسـت كه از صـفر تا دو نمره كذارى مى شـود؛ بنابراين مجموع نمرات از · تا مب در نوســان اســت (F9). نمرات بيشــتر در اين

1. Internal consistency

2. Beck's Depression Inventory-II (BDI-II)

3. Hamilton Depression Rating Scale (HDRS)

4. Scale for Suicide Ideation

5. Suicide risk scale

6. Goldberg General Health Questionnaire (GHQ) 
شـناختى، توجهى، و رفتارى است. اين درمان رادر ده جلسه ·9 دقيقهاى انفر ادى مى توان اجرا كرد. در اين بزوهش به دليل گروهى بودن جلسات

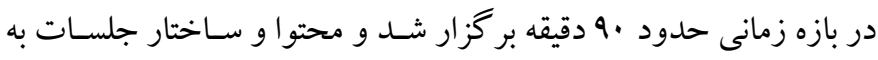
وسـيله متخصصان در اين حيطه مورد تأييد قرار گر فته است. سرفصل هاى جلسات اين درمان در جدول ا خزارش شده است.
ج) برنامه مداخلهاى: در اين مطالعه از دو نوع مداخله شناختى -رفتارى (צ) و فراشناختى (Y) براى گروههاى آزمايش استفاده شد:

الف) راهنماى درمان شناختى - رفتارى: درمان شناختى - رفتارى بر اى اختلال بدريختى بدن توسط ويل و نظير اغلو (4) طراحى شده است. هدف اين درمان بازسازى و اصلاح سو گيرىهاى

جدول 1: ساختار جلسات درمان شناختى_رفتارى

\begin{tabular}{|c|c|c|c|}
\hline تكاليف & محتواى جلسات & عنوان جلسات & 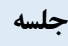 \\
\hline شناسايى اختلال و تعيين اهداف & تشخيص و ارزيابى & 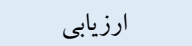 & يكم \\
\hline شناسايى مدل شخصى و افكار مرتبط با ظاهر & مفهومسازى و مشاركت مراجع در درمان & مفهوم سازى & 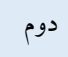 \\
\hline ي يِخيرى رفتارهاى مرتبط با ظاهر & توصيههايى درباره رويههاى مر تبط با ظاهر & رويههاى رفتارى & 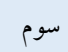 \\
\hline شناسايى ييوند بين افكار و احساسات & بازسازى سناريوهاى تصوير سازى & 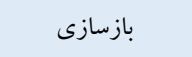 & جهارم \\
\hline شناسايى افكار منفى و ايجاد افكار جايخزين & اصلاح سو گيرىهاى توجهى & اصلاح سو گيرى & ينجم \\
\hline بيخيرى افكار مر تبط با ظاهر & اصلاح فرايندهاى شناختى & 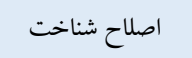 & ششم \\
\hline رويارويى با موقعيتهاى اضطراب آور و يِشيرى از تشريفات & رفتارهاى اجتنابى، وسواسى، و اطمينانجويى & رفتارهاى اجتنابى & هفتم \\
\hline ي بيشخيرى از باسخهاى مرتبط با امور زيبايىشناختى & اصلاح ارزيابىها و معكوس كردن عادتها & 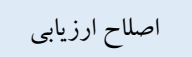 & 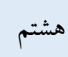 \\
\hline تمركز بر افكار افسرده كنده و انجام فعاليتهاى لذتبخش & فعالسازى رفتارى براى افسردگى & فعالسازى رفتارى & نهم \\
\hline ادامه تمرينات جلسههاى قبلى & يِيشخيرى از عود و اجراى بِ آزمون & ي يشخيرى از عود & نهم \\
\hline
\end{tabular}

محتواو سـاختار جلسـات به وسـيله متخصسصـان در اين حيطه مورد تأييد قرار گرفته اســت (Yس). اين درمان را در ده جلســه •4 دقيقهاى انفرادى مى توان اجرا كرد، ولى در اين يثوهش ·ـ جلســه •9 دقيقهاى كروهى مورد اسـتفاده قرار كرفت. سـرفصل هاى جلسات اين درمان در جدول r

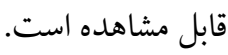

\section{ب) راهنماى درمان فراشناختى:}

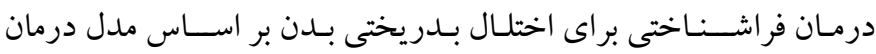
فر اشـناختى اختلال وسـواسى اجبارى توسط ولز (Y9) طراحى شده است. اين درمـان براى اختلالات طيف وســـواس بر خرفته از مدل فراشــــاختى است. هدف اصلى اين درمان بازدارى نشانگان توجه شناختى است (Y).

جدول r: ساختار جلسات مداخله فراشناختى

\begin{tabular}{|c|c|c|c|}
\hline تكاليف & محتواى جلسات & عنوان جلسات & 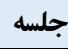 \\
\hline شناسايى اختلال و تعيين اهداف & تشخيص و ارزيابى & 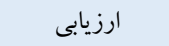 & يكم \\
\hline به كاركيرى رويارويى همراه با انجام ياسخ يا به تعويق انداختن تشريفات & مفهومسازى موردى، معرفى مدل و آمادهسازى & 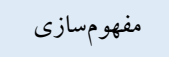 & دوم \\
\hline به كار كيرى ذهن آكاهى گسليده در مورد افكار مزاحم & تمرين ذهن آكاهى گسليده & ذهن آكاهى & 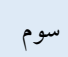 \\
\hline 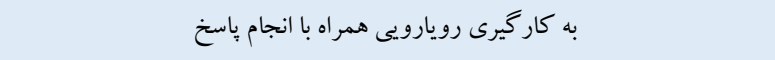 & رويارويى با و بدون انجام پِاسخ & 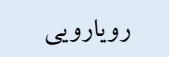 & جهارم \\
\hline به كار گيرى ذهن آكاهى گسليده در مورد افكار مزاحم اجراى آزمايشهاى رفتارى & كشاكش كلامى مر بوط به آميختكى & 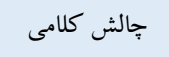 & ينجم \\
\hline تمرين آكاهى از يايش تهديد و كنار كذاشتن آن & ت تحليل سود و زيان & تحليل & ششم \\
\hline باز گشت به روند قبل از رويداد راهانداز و به كارگيرى راهبردهاى جديد & آموزش تمركز مجدد و توجه & 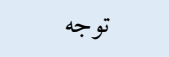 & هفتم \\
\hline خوددارى از نخرانى، نشخوار فكرى، و يايش تهديد & فعاليت روى نخر انى، نشخوار فكرى و باورها & 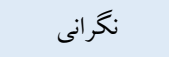 & هشتم \\
\hline مرور مقابله غير انطباقى باقيمانده & وارسى هر گونه باور باقىمانده & باورها & نهم \\
\hline مشخص كردن كاربردهاى مداوم درمان & يِيشيرى از عود و اجراى بِ آزمون & ي يِشيرى از عود & .1 \\
\hline
\end{tabular}


ســه ماهه، به طور خلاصسه ه جلسـه آموزش مهارت هاى لازم را دريافت كردند.

در اين بثزوهش براى تحليل دادهها با توجه به طرح بثوهش در مرحله بيخيرى از روش اندازه كيرى مكرر ' اســفاده شــد. دادهها در محيط نرم افزار SPSS-26 - تحليل شدند.

كافتها در اين مطـالعـه بر اســاس عـامـل درون آزمودنى يعنى زمـان اندازه گيرى متغيرهـا و عـامـل بين آزمودنى يا عضــويت در خروهه هاى مطالعه، دادهها تحليل شـد. بررسى شر ايط بيش شرطهاى اجراى اندازه گيرى مكرر نشان داده كـه دادههـا داراى توزيع بهنجار هســتند، واريانس هاى بيش آزمون متغيرهاى وابسته دو گرووه آزمايش و گروه گو اه تفاوت معنادارى ندارند، و آزمونهـاى شــاييرو-ويلكك، كـالمو گروف -اســميرنوف، و آزمون

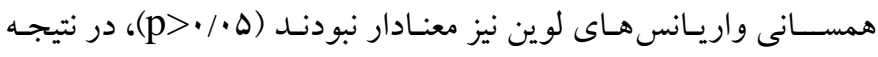
شرطهاى اجراى تحليل هاى آمارى برقرار است. در جــدول بانتـايج تحليـل واريـانس متغيرهـاى وابســــه در مرحلـه بيش آزمون، و همين طور نتـايج انـدازه كيرى مكرر در مرحله ييخيرى به علـاوه ميـانكين و انحراف اســــانـدارد اين متغير بـه تفكيـك مراحـل

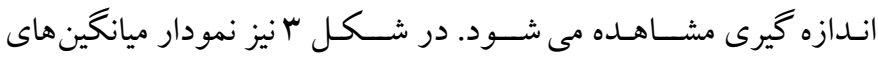
كروههاى آزمايش و گروه گو اه در سه مرحله نمايش داده شده است.
د) روش اجر ا: اين يثزوهش با كسب مجوز كتبى از دانشگاه آزاد اسلامى واحد شــاهرود و با هماهنكى در يكى از دبيرســـانهاى منطقه • ا تهران اجرا شــــ MF نفر از جـامعـه مورد مطالعه يس از ارزيابى اوليه توســــ يرسـشـنامه ترس از تصـوير بدن داراى علائم بيش بالينى اختلال بدريختى بدن تشـخيص داده شـدند و يس از بررسى ملاككهاى ورود و خروج الها دانش آموز بر حســب ملـاككهاى ورود و خروج به عنوان نهايى انتخاب

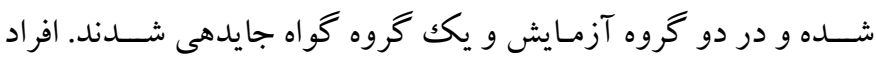
كروهازمايشى مداخلات للزم ذكر شـده رد بخش قبلى رادريافت كردند كه توسط نويسـنده نخست اين مقاله با سـابقه V سـال انجام شــ (لازم به ذكر اســت مجرى اين مـداخلـات داراى ســابقـه طولانى در درمان و از كو اهى هـا و تـأيـديـهـهـاى لـازم علمى برخوردار بودند). دادههاى للازم با

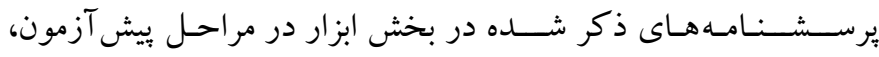
يس آزمون، و بيخيرى از افراد نمونه هر سـه گروه جمع آورى شد. لازم به ذكر اسـت كه رعايت نكات اخلاقى در اين بزٔوهش به دقت اجرا شــد و رضـايت آكاهانه شـركت كنند كان و والدين آنها كسـب شـــ. رضـايت آكَاهـانـه شــامـل اطلـاعـاتى در مورد روش مداخله، روش نمونه كيرى، جـايسـهى تصــادفى، تعـداد و مـدت زمـان جلســات، رازدارى، حريم خصــوصسى شـر كت كنند كان، آكاهى از نتيجه درمان، و حق خروج از

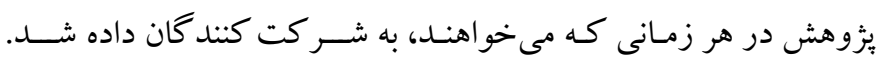
همجنين موافقت افراد نمونه و والدينشــان براى شــر كت در يزوهش به

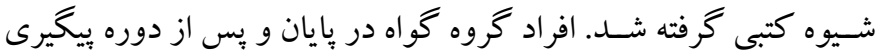

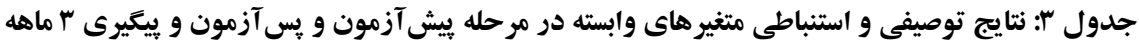

\begin{tabular}{|c|c|c|c|c|c|c|c|c|c|c|}
\hline \multicolumn{3}{|c|}{ مقايسههاى جفتى شفه } & \multirow[b]{2}{*}{$\eta^{r}$} & \multirow[b]{2}{*}{$\mathbf{P}$} & \multirow[b]{2}{*}{$\mathbf{F}$} & \multirow[b]{2}{*}{ فراشناختى } & \multirow{2}{*}{ شناختى - رفتارى } & \multirow[b]{2}{*}{ فهرست انتظار } & \multirow[b]{2}{*}{ مرحله } & \multirow[b]{2}{*}{ مقياس } \\
\hline فراشناختى با & شا فهرستى -رفتارى & شا شاختى -رفتارى & & & & & & & & \\
\hline $.19 \mathrm{~V}$ & . $/ 4 F$ & $\cdot / V F$ & - & $\cdot / N F$ & $\cdot / \mu 1$ & $\mid F / 9 F(9 / 9)$. & $\mid F / \pi \Delta(F / \Delta r)$ & $|\Delta / V|(Y / Q Y)$ & ييش آزمون & \\
\hline- & - & - & - & - & - & $1 . / 9 F(F / 9 \cdot)$ & $G / Y F(Y / \Lambda \cdot)$ & $1 \Delta / \Gamma^{\prime}(\Gamma / \cdot r)$ & بِ آزمون & افسردحىى \\
\hline$\cdot / \cdot \Delta$ &.$/ \cdot 1$ & $\cdot / \cdot \Delta$ & $\cdot / \mathrm{TV}$ &.$/ \cdot 1$ & $1 \% / 9 V$ & $1 . / \Lambda(F / M r)$ & $\Delta / Q F\left(Y / \Gamma_{\cdot}\right)$ & $1 \Delta / T^{\prime} q(r / Y V)$ & ييخيرى & \\
\hline r & $\cdot / 4$. & $\cdot / \cdot V$ & - & $\cdot / r$ & I/VY & $1 Q / M(F / Y \Lambda)$ & $|r / V|(\Delta / Y \Lambda)$ & $\mid \Psi / \backslash \Lambda\left(\Delta / \Psi^{\prime} \Lambda\right)$ & ي يش آزمون & الحبل شا \\
\hline - & - & - & - & - & - & $1 \cdot / T(Y / \Delta \Delta)$ & $\operatorname{N/Ar}(r / F \mid)$ & $1 \% / .9(\Delta / 9 \mathrm{~V})$ & يس آزمون & \\
\hline$\cdot / \cdot \Delta$ & $\cdot / \cdot r$ & $\cdot / \Delta 9$ & ./Ir &.$/ \cdot r$ & $r / 94$ & $1 \cdot / Y F(Y / \Delta I)$ & 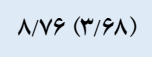 & $\mid q / \cdots(\Delta / 9 \mid)$ & بيخيرى & \\
\hline$\cdot / 9$. & .194 & $\cdot / 21$ & - & $\cdot / A V$ & $\cdot / l F$ & $r / 1 Y(1 / \% 4)$ & $1 / 9 F(1 / r \Delta)$ & $r / M \Lambda(I / F r)$ & ي بيش آزمون & 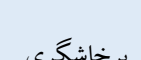 \\
\hline - & - & - & - & - & - & I/ $\Delta \Delta(\cdot / 4)$ & $1 / \cdot 9(\cdot / V \Delta)$ & $1 / M(1 / F \mid)$ & يس آزمون & خودآزاري \\
\hline.$/ .4$ &.$/ . \Delta$ &.$/ 99$ & $\cdot / 1 r$ & $\cdot 1 \cdot \Delta$ & $r / \pi$ & $1 / \cdot 9(\cdot / \wedge r)$ & $\cdot / 90(\cdot / 49)$ & $r / r F\left(I / r^{\prime}\right)$ & ييخيرى & \\
\hline
\end{tabular}


تحليل مدلهاى خطى عمومى ' مرحله يّ آزمون بر اسـاس اندازه كيرى

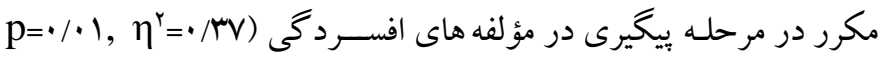

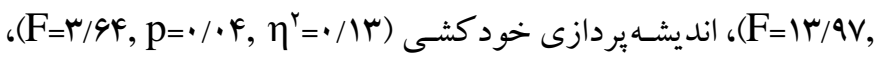

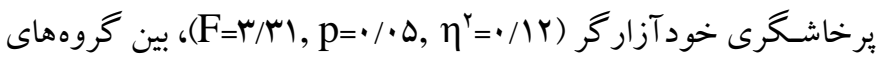
مورد مطالعه تفاوت معنادارى وجود دارد. نتايج مقايسـه جفتى شـفه نشان داد كـه هر جنـــ هر دو درمان در مقايســهـ با فهرســت انتظار درمان هايى اثربخش بودهاند (ه •/p)، اما درمان شـناختى -رفتارى نسـبت به درمان

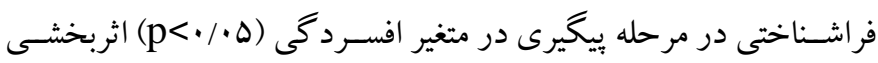

$$
\text { بيشترى داشته است. }
$$

در شــكل ا رونــ تغيير نمرههـاى ميـانكين هاى گروههاى آزمايش وكروه كواه در ســه مرحله بيش آزمون، يس آزمون، و بيخيرى قـابـل

مشاهده است.

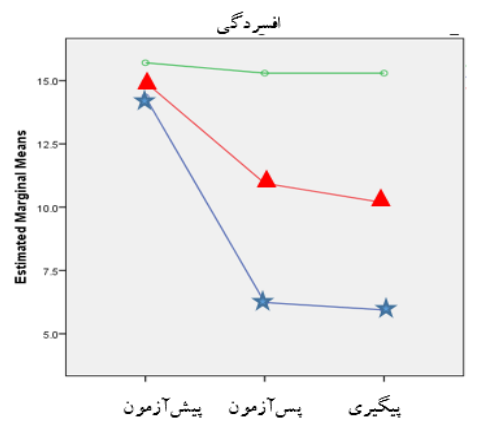

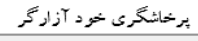
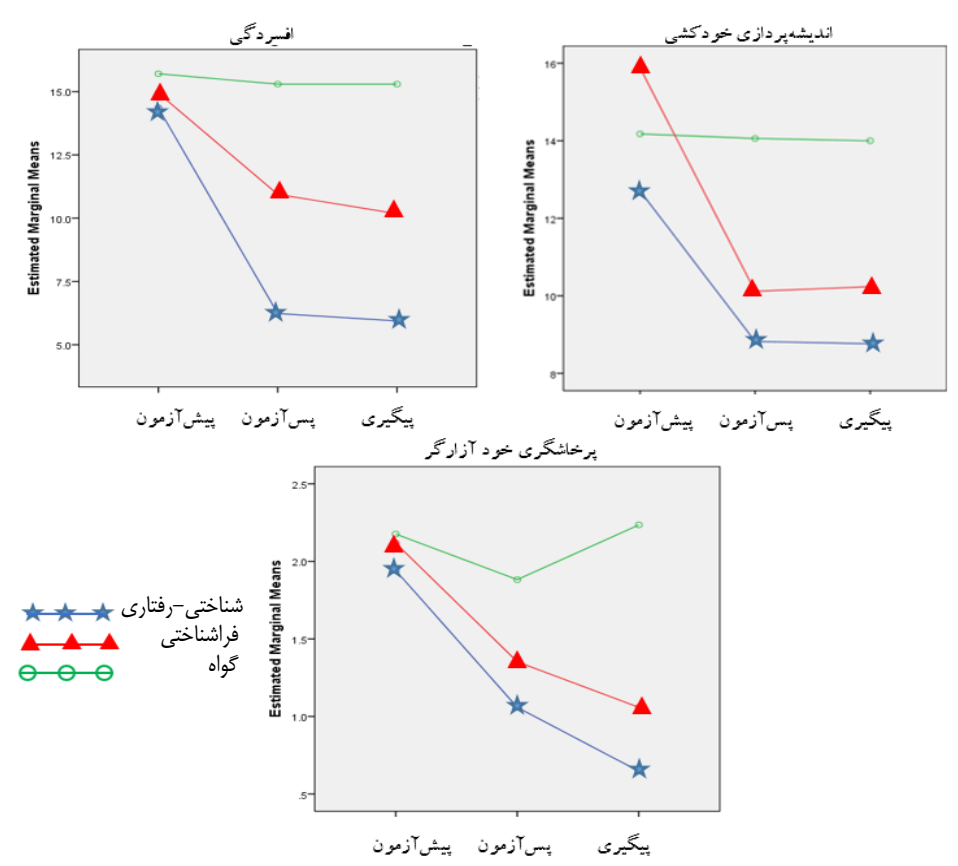

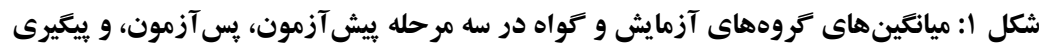

\section{بحث و نتيجه تيرى}

هدف اين بزظوهش مقايســه اثربخشــى درمان هاى شــناختى - رفتارى و

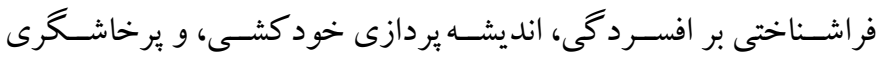
خود آزارگر افر اد با نشـانه هاى بيش بالينى اختلال بدريختى بدن بود. نتايج

در جـدول ب ميـانخين و انحر اف اســتـانـدارد متغيرهاى افســردكى، انديشـهـيردازى خود كشى، و يرخاشكرى خود آزارگر در مراحل مختلف اندازه گيرى قابل مشاهده است. همان طور كه در رديف هاى بيش آزمون سه متغير در جدول ب مشاهده مىشود نتايج تحليل واريانس يككطرفه بين

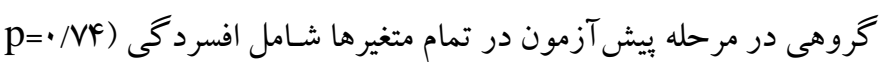

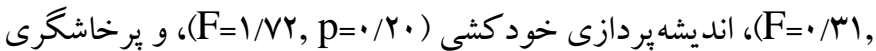

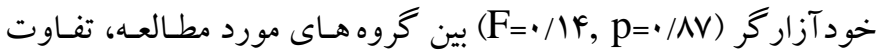
معنـادارى وجود نـدارد. اين يـافتـه نشــان مىدهـــ علاوه بر بهنجار بودن شـاخص هاى بر اكندگى، شاخص هاى گر ايش مركزى بين گرووها در نيز يكسان است؛ به عبارت ديخر اين يافته نشان مىدهد كه جايدهى تصادفى باعث تفاوت كروهها در ابتداى كار نشــده اسـت. به علاوه، نتايج تحليل واريانس اندازه گيرى مكرر در مرحله بيخيرى قابل مشـاهده اسـت. نتايج
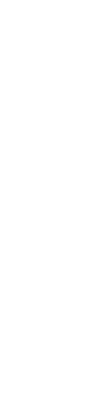
اختلال عملكردى دارند؛ هر جند ميز ان بالاى شدت علائم نتيجه درمانى را به طور معنادارى بيشبينى نكرده بودند (YY)

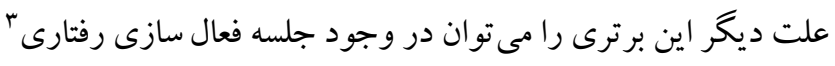

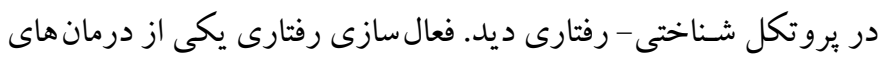

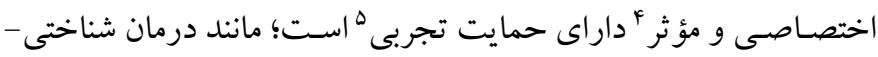

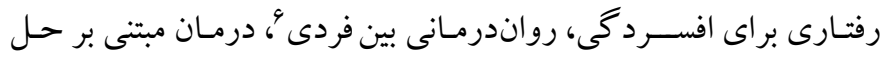

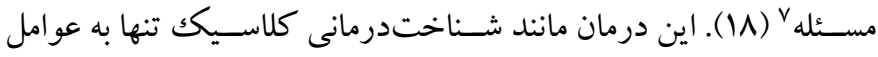

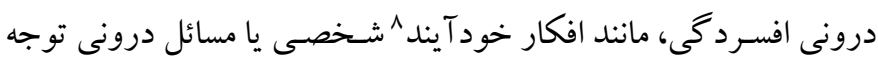

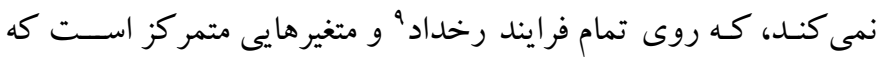

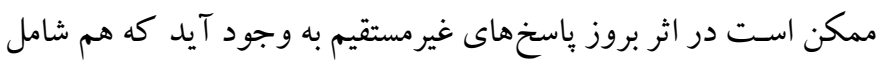

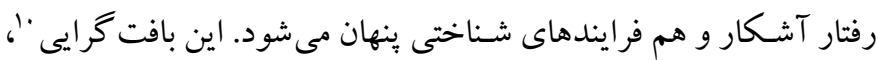

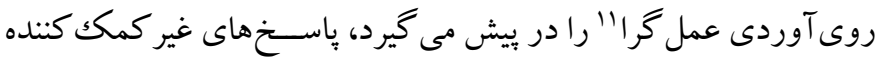

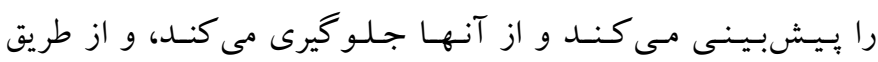

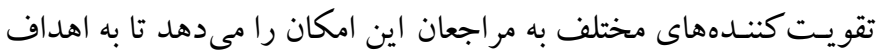
خود دست يابند.

در درمـان شــناختى -رفتارى درمانكر توضـيحات مثبتى را درمورد

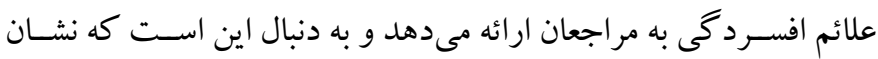

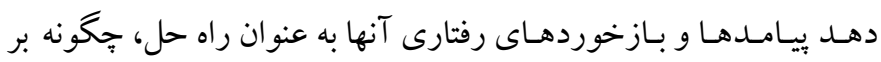

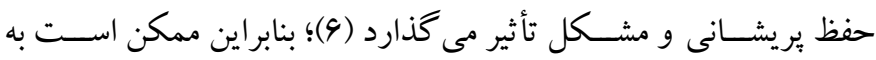

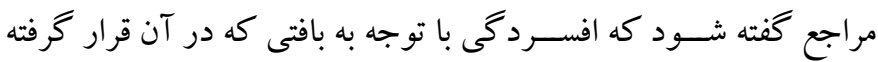
اسـت، بسيار قابل دركك اسـت. علاوه بر اين، تجربه افسرد گحى به عنوان

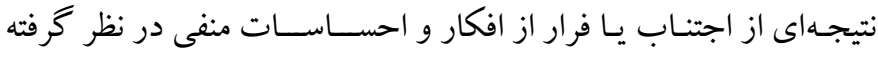

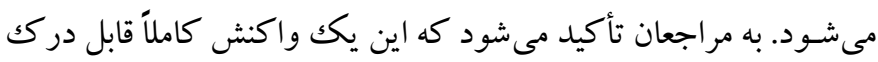

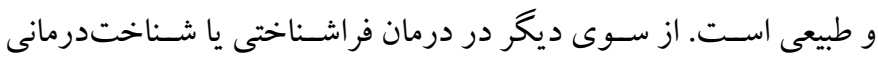

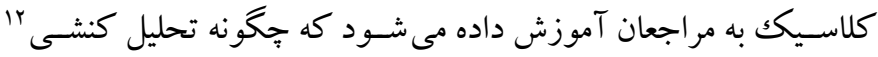

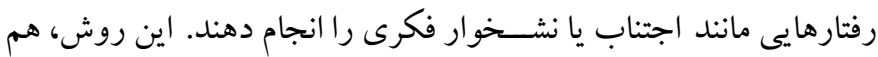
فعـاليـتهـاى عـادى و هم تعـامـل هـاى اجتمـاعى فرد را تحـت تأثير قرار مىدهد كه كاهى از طريق اجتناب باعث مى شـود كه وى افسردهتر شود،

7. Problem-solving therapy

8. Automatic thought

9. Event

10. Contextualism

11. Pragmatic approach

12. Functional analysis
يُزوهش نشــان مىدهد كه به طور كلى در تمامى متغيرهاى وابــته، اين

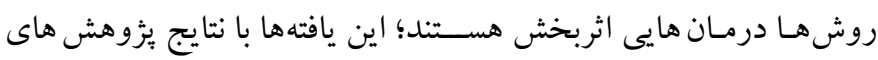

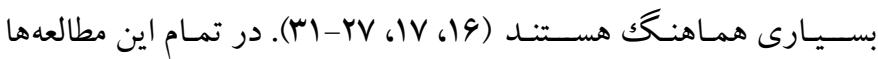
درمانهاى شـناختى-رفتارى و فراشناختى در كاهش افسردگى تأثير كذار

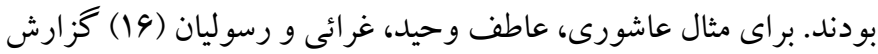
كردند كه هم درمان شـناختى -رفتارى و هم درمان فراشناختى در كاهش

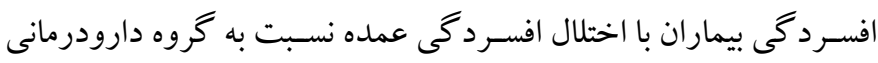

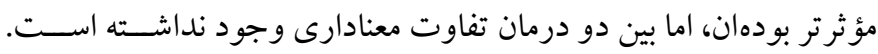

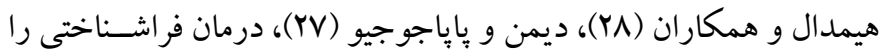

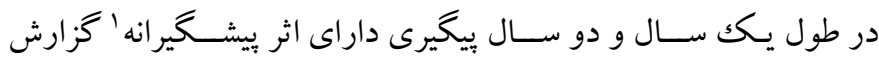

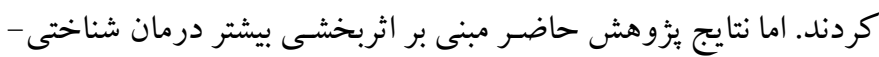

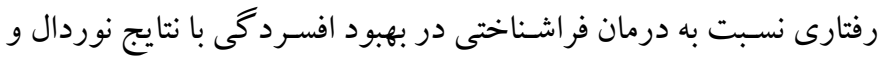

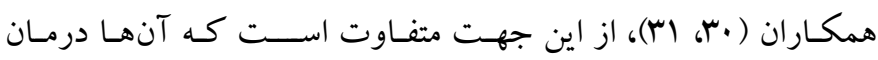
فر اشـناختى را داراى اثربخشى بيشترى نسبت به درمان شناختى -رفتارى

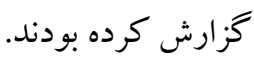
اولين علت اين موضـوع كه درمان شـناختى -رفتارى نسـبت به درمان

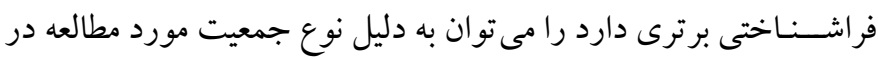

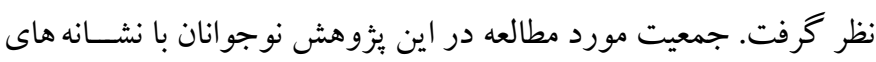

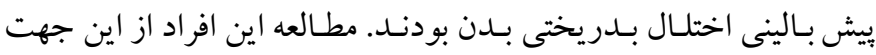

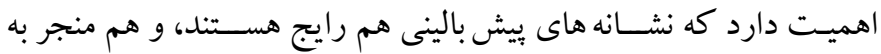
مختل شـدن عملكرد مىشـوند (q") و همجنين مطالعه آنها مى تواند نشان

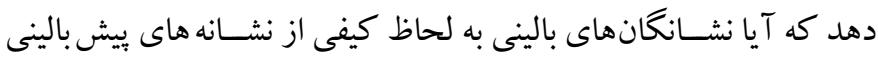

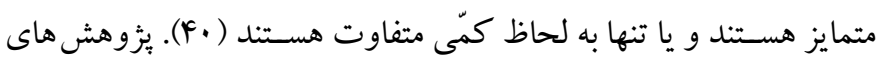
بيشين بارها نشان دادهاند كه درمان شناختى - رفتارى در افراد با نشانه هاى

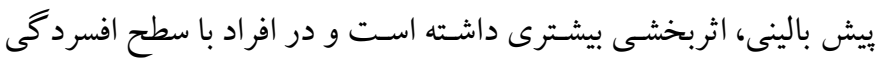

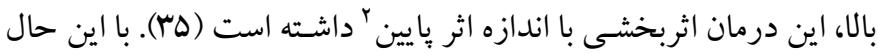
يزؤهشى ديخر نشـان داده اسـت كه درمان شناختى -رفتارى براى اختلال

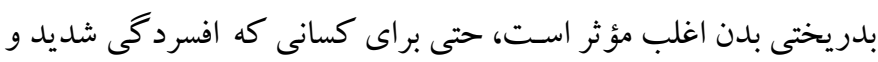

1. Prophylactic effect

2. Low effect size

3. Behavioral activation

4. Efficacious and specific

5. Empirically supported treatments

6. Interpersonal psychotherapy 


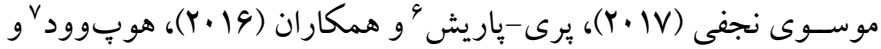

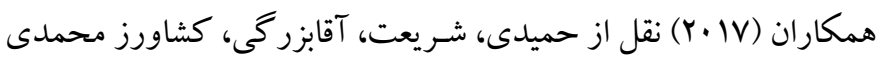

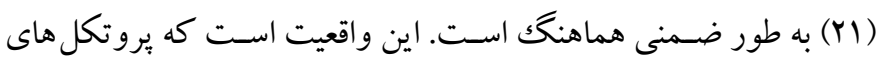

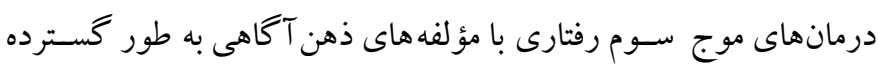
براى بيشتر مشكلات روان شناختى كاربرد مطلوبى دارند؛ بنابر اين در تبيين

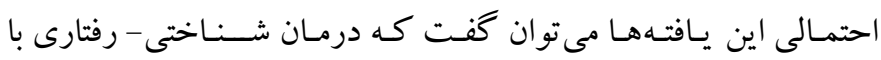

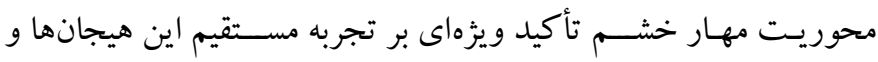

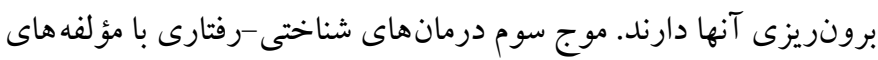

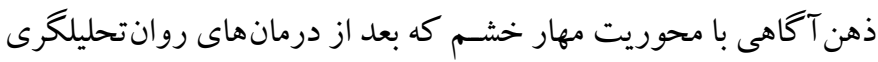

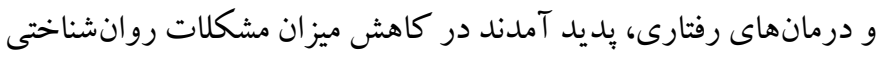

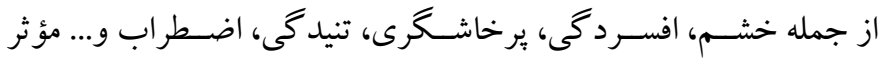

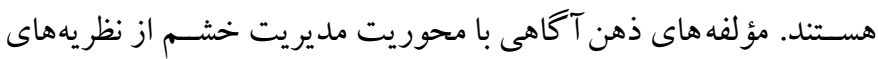

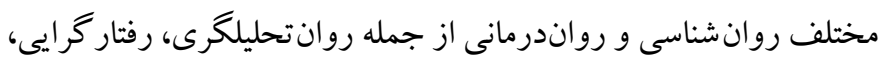

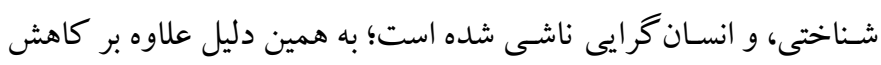
بيشتر علائم اختلالها و مشكلهاى روان شناختى بر توسعه جنبه هاى مثبت

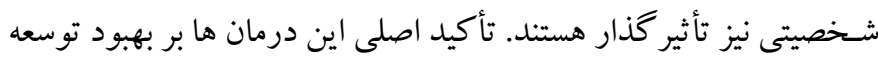

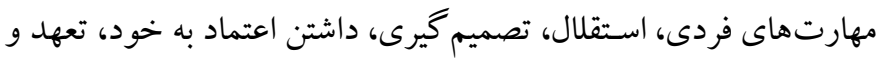

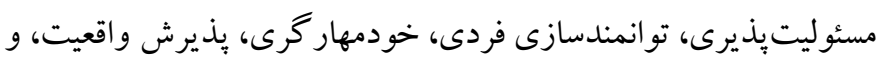

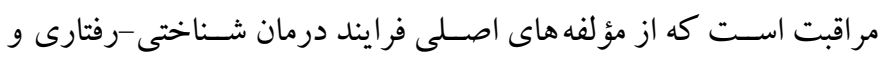
درمان فراشـناختى هسـتند. در طى فرايند مداخله هاى درمانى شـناختى رفتارى و فراشـناختى تكنيك ذهن آكاهى، مهار و اداره كردن هيجانات

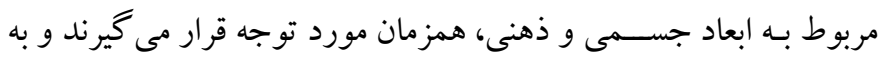

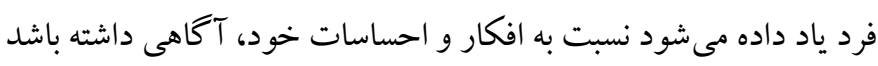

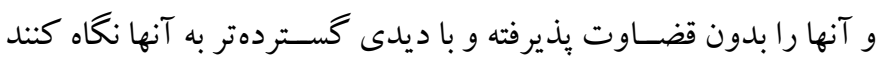

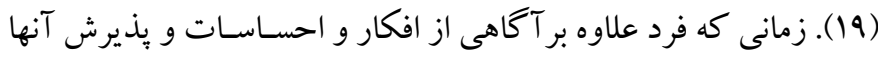

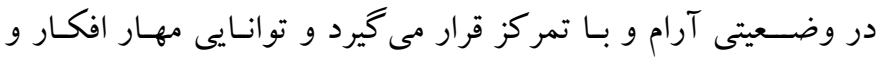

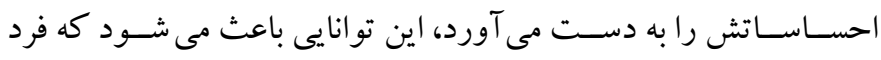

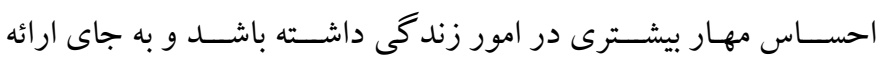

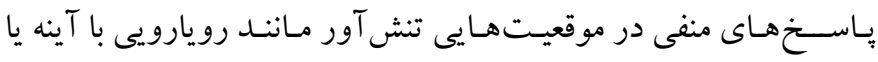

7. Hopewood
نشـخوار فكرى بيشـترى داشـته باشـد، و تجربياتى رادر زندگى از دسـت دهد كه به طور معمول رضايت يا لذت را به ارمغان مى آورد. علـاوه بر همسه اين موارد، شـيوه عملكرد فرد بر ديخران و محيط مى تواند تأثير بحذارد و در نتيجه افسـردگى را يا تشــيد كرده يا كاهش دهـد. در اين يزوهش افســردگى بـه عنوان نتيجهاى از اجتناب يا فرار از افكار ناخوشايند يا تصاويرى درباره زشت بودن، عدم موفقيت يا احساس شــرم، و همجينين كناره گيرى اجتماعى تلقى شــــ. اين اجتناب منجر به كمتر شـــدن ســطح تقويت مثبت و در نتيجه كاهش خزانه تقويتى افراد تلقى شـــده اســتـ. از همين روى راهبردهاى مقابله و كنار آمدن ثانويه' مـانـــد كنـاره گيرى بـه عنوان تجربهاى كه افسـردگى را حفظ مى كنند، شــناخته مى شــوند كه در نهايت منجر به انديشــهـ بردازى خود كشـى و

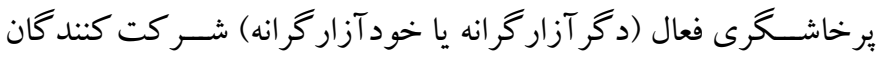
مى شـود. مثلاً ياسـخ هاى احساس شرم و عواقب ناخو استه آن بر افراد مهم زندگى كه شامل خانو اده و دوستان مىشود تأثير منفى مى گذارد؛ افرادى كه به عنوان منابع حمايتى `ُشـناخته مى شـوند. رفتارهاى مقابلهاى و كنار آمدن ثانويه در فعال ســازى رفتارى، كه در درمان شــناختى -رفتارى در همه انواع افسـردگى مورد توجه قرار مى گيرد؛ به خصـوص هنگامى كه فرد از عو امل تسريع كننده بافسردگى مانند آنجه ذكر شد، آكاهى نداشته

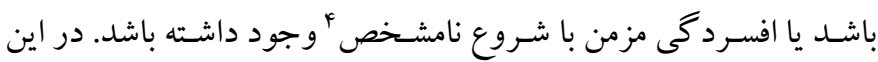
شرايط به فرد كمكك مى شود تا اين رفتارهاى اجتنابى را بشكند و با وجود

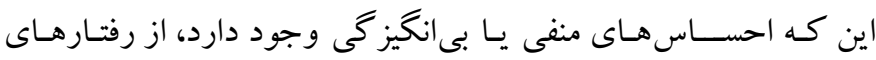
نزديككشـونده هبجاى رفتارهاى اجتنابى استفاده كند ( •Y). در اين شرايط اجتــاب از تجربـه در طولانى مـدت به عنوان وضــعيتى قابل دركى تلقى مى شود كه كمكى به بهبود شرايط نمى كند. درباره فرضـيه هاى دوم و سـوم اين يزوهش مبنى بر مقايسه اثربخشى درمانهاى شـناختى - رفتارى و فراشـناختى بر انديشه يردازى خود كشى و يرخاشــرى خود آزارگ افر اد با نشـانه هاى بيش بالينى اختلال بدريختى بــدن ، تفـاوتى بين دو روش درمـانى مشـــاهــده نشـــــ ولى هر دو روش مداخلههايى اثربخش بودند. اين يافته با بزوهش هاى قاسـمى بيســـانى و

1. Secondary coping strategies

2. Supportive resources

3. Precipitating factors

4. No obvious onset chronic depression 
مى تواند به طور غيرمستقيم منجر به سو گيرى شده باشد. بيشنهاد مى شود

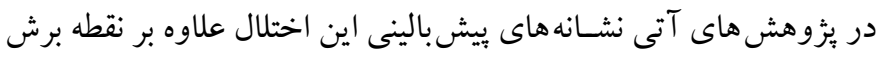

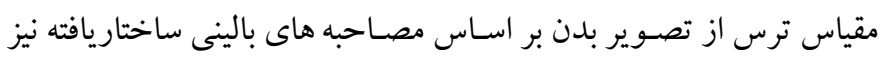

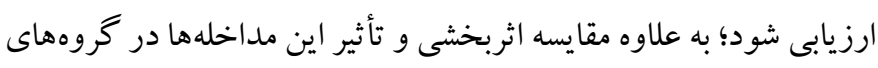

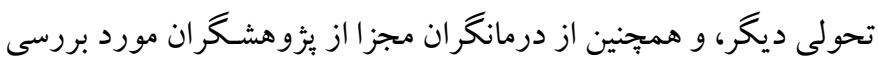

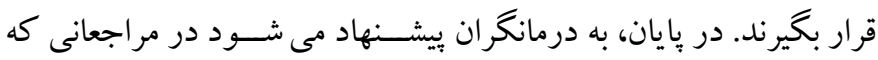
داراى علائم افسردگى هستند، مولفههاى فعالسازى رفتارى راد در درمان

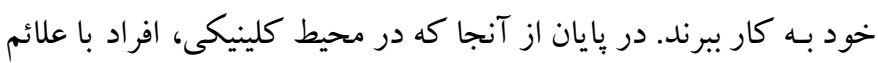

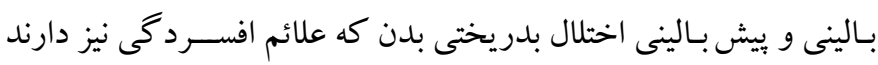

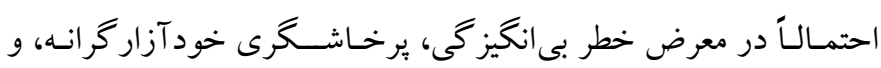

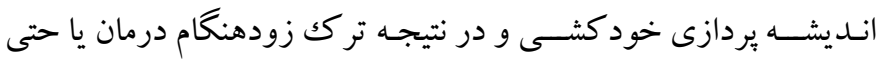

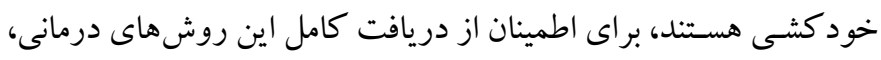

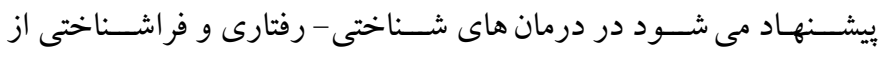

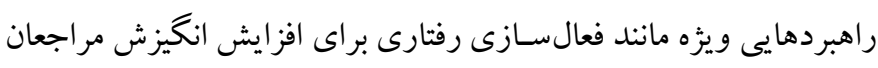
و مؤلفه هاى ذهن آكاهى استفاده شود. ملاحظات اخلاقى

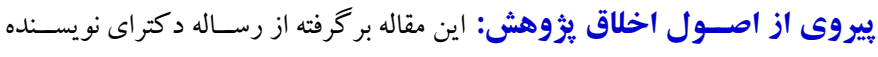

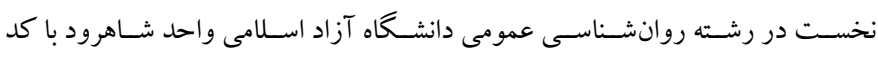

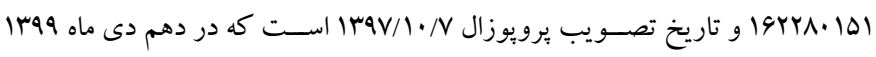

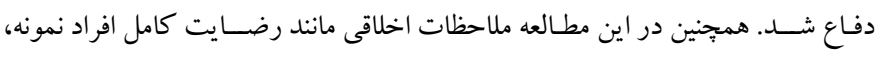

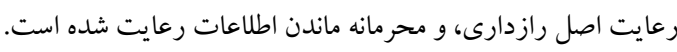

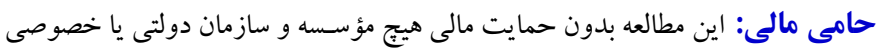

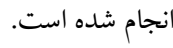
نقش هر يكك از نويسند كان: اين مقاله از رساله دكتراى نويسنده اول و به راهنمايى نويسند كان دوم و سوم استخراج شده است.

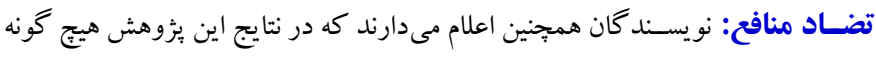
تضاد منافعى وجود ندارد.

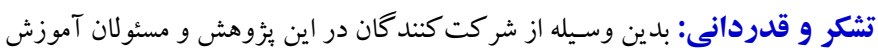
و يرورش منطقه · ا تهران كه اجراى اين يُوهش را ميســر كردند تشـكر و قدردانى مىشود.
ســطى انعكاسـى بـا مهار گرى و حفظ آرامش و آكاهى بيشــترى با

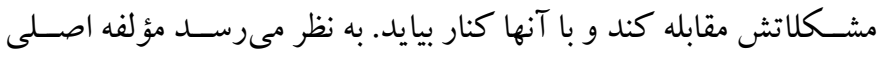
ذهن آكَاهى كه در درمان فراشـناختى به عنوان ذهن آكاهى گعسـليده

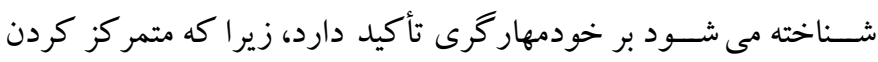

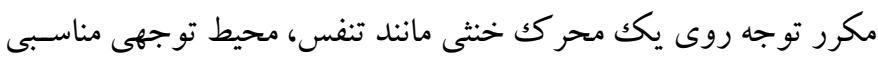
به وجود مى آورد و فرد را از اشـتغال ذهنى و يا از افكار تهديد كننده، باز

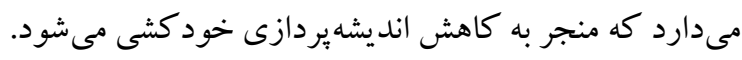

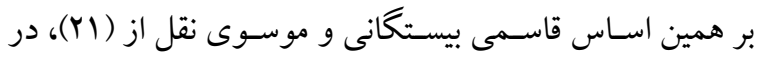

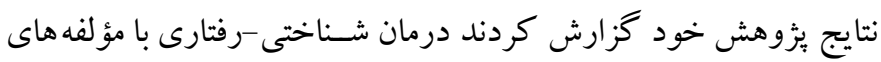

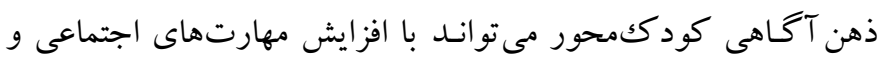

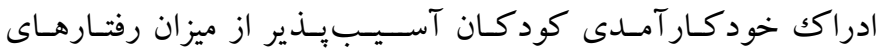

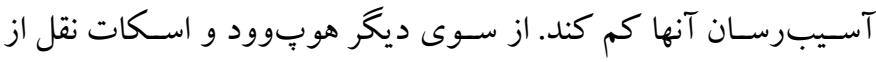
(YI) (Y)، در فراتحليلى نشــان دادند كه بر اســاس كار آيى بالينى، درمان

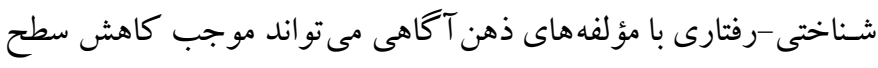

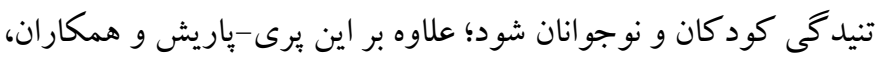

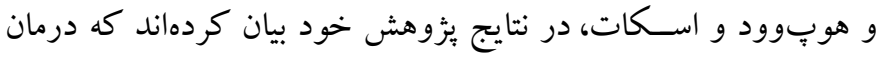

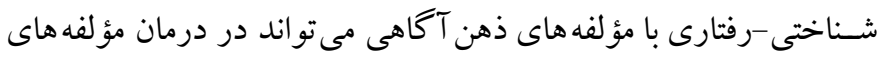

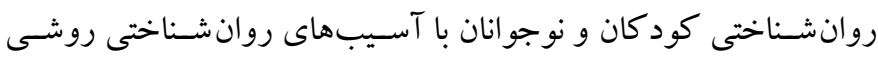

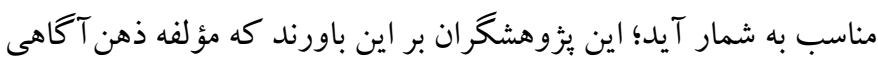

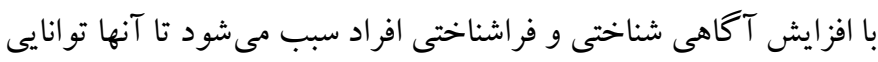

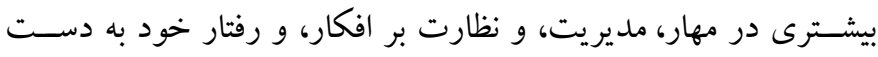

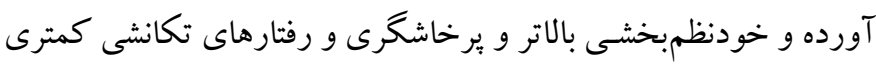

را تجربه كنند؛ نقل از (Y) اين بززوهش داراى محسدوديـت هـايى نيز بود. ابتـدا، اين بزوهش در دانش آموزان نوجو ان اجرا شــــه اســت، نشـــانه هاى بيش بالينى اختلال بـدريختى بــدن مى توانتـد بـه عنوان علائم تحولى بهنجار مورد توجه قرار

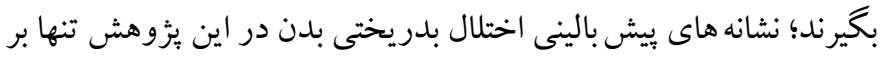

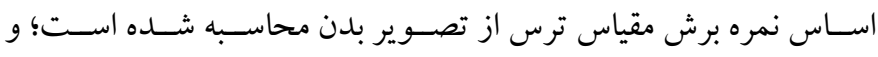

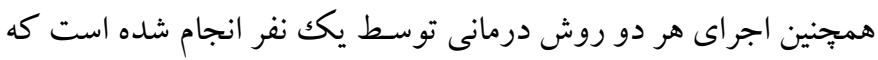




\section{References}

1. American Psychiatric Association. Diagnostic and Statistical Manual of Mental Disorders. 5 ed. Washington DC: American Psychiatric Association; 2013, pp: 242-247. Doi: 10.1176/appi.books. 978089 0425596 [Link]

2. Summers BJ, Aalbers G, Jones PJ, McNally RJ, Phillips KA, Wilhelm S. A network perspective on body dysmorphic disorder and major depressive disorder. J Affect Disord. 2020;262:165-73. Doi: 10.1016/j.jad.2019.11.011 [Link]

3. Buhlmann U, Glaesmer H, Mewes R, Fama JM, Wilhelm S, Brähler E, et al. Updates on the prevalence of body dysmorphic disorder: A population-based survey. Psychiatry Res. 2010;178(1):171-5. Doi: 10.1016/j.psychres.2009.05.002 [Link]

4. Weingarden H, Renshaw KD, Wilhelm S, Tangney JP, DiMauro J. Anxiety and Shame as Risk Factors for Depression, Suicidality, and Functional Impairment in Body Dysmorphic Disorder and Obsessive Compulsive Disorder. J Nerv Ment Dis. 2016;204 (11) :832-9. Doi: 10.1097/NMD.0000000000000498 [Link]

5. Shaw AM, Arditte Hall KA, Rosenfield E, Timpano KR. Body dysmorphic disorder symptoms and risk for suicide: The role of depression. Body Image. 2016;19:169-74. Doi: 10.1016/j.bodyim.2016.09.007 [Link]

6. Veale D, Neziroglu F. Body Dysmorphic Disorder: A Treatment Manual. Chichester, West Sussex, UK: Wiley-Blackwell; 2010 , pp: 351 \& 362. [Link]

7. Phillips KA. Suicidality in Body Dysmorphic Disorder. Prim psychiatry. 2007;14(12):58-66. [Link]

8. Veale D, Gournay K, Dryden W, Boocock A, Shah F, Willson R, Walburn J. Body dysmorphic disorder: a cognitive behavioural model and pilot randomised controlled trial. Behav Res Ther. 1996 Sep;34(9):71729. doi: 10.1016/0005-7967(96)00025-3 [Link]

9. Phillips KA, Coles ME, Menard W, Yen S, Fay C, Weisberg RB. Suicidal ideation and suicide attempts in body dysmorphic disorder. J Clin Psychiatry. 2005;66(6):717-25. [Link]

10. Cotterill JA. Dermatological non-disease: a common and potentially fatal disturbance of cutaneous body image. Br J Dermatol. 1981;104(6):611-9. Doi: 10.1111/j.1365-2133.1981.tb00746.x [Link]

11. Brown SL, Roush JF, Mitchell SM, Cukrowicz KC. Suicide Risk Among BDSM Practitioners: The Role of Acquired Capability for Suicide. J Clin Psychol.
2017;73(12):1642-54. Doi: 10.1111/j.1365-2133. 19 81.tb00746.x [Link]

12. Goldblatt MJ. Suicide and masochism: The evolving relationship between guilt, suffering, self-attack and suicide. Psychoanal Psychother. 2010;24(2):93-100. Doi: 10.1080/02668731003707733 [Link]

13. Alavizadeh SM, Sobhi Gharamaleki N, Mami S, Mohammadzadeh J, Ahmadi V. Development and Validation of Sport Aggression Styles Inventory: An instrument based on Millon's personality theory. J Psychometry. 2020;8(32):65-80. [Persian]. [Link]

14. Smith JM, Gacono CB, Cunliffe TB. Female Psychopathy and Aggression: A Study with Incarcerated Women and Rorschach Aggression Scores. J. Aggress. Maltreatment Trauma. 2020;29(8): 936-52. Doi: 10.1080/10926771.2020. 1738614 [Link]

15. Butler AC, Chapman JE, Forman EM, Beck AT. The empirical status of cognitive-behavioral therapy: A review of meta-analyses. Clin Psychol Rev. 2006;26(1):17-31. Doi: 10.1016/j.cpr.2005.07.003 [Link]

16. Ashouri A, Atef Vahid MK, Gharaee B, Rasoulian M. Effectiveness of meta-cognitive and cognitivebehavioral therapy in patients with major depressive disorder. Iran J Psychiatry Behav Sci. 2013;7(2):2434. [Link]

17. Mojtabaei M, Alavizadeh SM. Comparative Effectiveness of Meta-Cognitive Therapy (MCT) and Cognitive Behavioral Therapy (CBT) on Decreasing Anxiety and Worry of Participants with Generalized Anxiety Disorder. Psychological Researches. 2017; 20(1):37-52. [Persian]. [Link]

18. Hollon SD, Ponniah K. A review of empirically supported psychological therapies for mood disorders in adults. Depress Anxiety. 2010;27(10):891-932. Doi:10.1002/da.20741 [Link]

19. Badpa K, Shirazi M, Arab A. The Effectiveness of Cognitive Behavioral Therapy Based on Mindfulness on Anger Control of Male Students. J Child Ment Health. 2019;5(4):159-68. [Persian]. [Link]

20. Veale D, Willson R. Manage Your Mood: How to Use Behavioural Activation Techniques to Overcome Depression. London: Robinson; 2015, pp: 51\&153. [Link]

21. Hamidi M, Shariat S, Aghabozorgi S, Keshavarz Mohammadi R. The Effectiveness of Child-based Mindfulness Program on Impulsivity and Aggression in Children with Externalizing Disorders. J Child Ment Health. 2020;6(4):144-55. [Persian]. [Link] 
22. Greenberg JL, Phillips KA, Steketee G, Hoeppner SS, Wilhelm S. Predictors of Response to CognitiveBehavioral Therapy for Body Dysmorphic Disorder. Behavior Therapy. 2019;50(4):839-49. Doi:10.1016/ j.beth.2018.12.008 [Link]

23. Fisher PL. The efficacy of psychological treatments for generalized anxiety disorder? In: Davey GCL, Wells A, editors. Worry and its psychological disorders: Theory, assessment and treatment. Chichester, UK: Wiley 2006. p. 359-77. [Link]

24. Mohajerin B, Bakhtiyar M, Olesnycky OS, Dolatshahi B, Motabi F. Application of a transdiagnostic treatment for emotional disorders to body dysmorphic disorder: A randomized controlled trial. J Affect Disord. 2019;245:637-44. Doi: 10.1016/ j.jad.2018.11.058 [Link]

25. Cuijpers P, Smit F, Oostenbrink J, de Graaf R, Ten Have M, Beekman A. Economic costs of minor depression: a population-based study. Acta Psychiatr Scand. 2007;115(3):229-36. Doi: 10.1111/j.16000447.2006.00851.x [Link]

26. Wells A. Metacognitive therapy for anxiety and depression. New York: Guilford Press; 2009, pp: 154 \&196. [Link]

27. Dammen T, Papageorgiou C, Wells A. A Two Year Follow up Study of Group Metacognitive Therapy for Depression in Norway. Journal of Depression and Anxiety. 2016;5(2):1-4. Doi: 10.4172/2167-1044. 100 0227 [Link]

28. Hjemdal O, Solem S, Hagen R, Kennair LEO, Nordahl HM, Wells A. A Randomized Controlled Trial of Metacognitive Therapy for Depression: Analysis of 1-Year Follow-Up. Front Psychol. 2019;10:1842. Doi: 10.3389/fpsyg.2019.01842 [Link]

29. Johnson SU, Hoffart A, Nordahl HM, Wampold BE. Metacognitive therapy versus disorder-specific CBT for comorbid anxiety disorders: A randomized controlled trial. J Anx Disord. 2017;50:103-12 Doi: 10.1016/j.janxdis.2017.06.004 . [Link]

30. Nordahl HM. Effectiveness of Brief Metacognitive Therapy versus Cognitive-Behavioral Therapy in a General Outpatient Setting. International Journal of Cognitive Therapy. 2009;2(2):152-9. Doi: 10.1521/ ijct.2009.2.2.152 [Link]

31. Nordahl HM, Borkovec TD, Hagen R, Kennair LEO, Hjemdal O, Solem S, et al. Metacognitive therapy versus cognitive-behavioural therapy in adults with generalised anxiety disorder. BJPsych Open. 2018;4(5):393-400. Doi: 10.1192/bjo.2018.54 [Link]

32. Rabiei M, Mulkens S, Kalantari M, Molavi H, Bahrami F. Metacognitive therapy for body dysmorphic disorder patients in Iran: Acceptability and proof of concept. J Behav Ther Exp Psychiatry. 2012;43(2):724-9. Doi: 10.1016/j.jbtep.2011.09.013 [Link]

33. National Collaborating Centre for Mental H. National Institute for Health and Clinical Excellence: Guidance. Obsessive-Compulsive Disorder: Core Interventions in the Treatment of ObsessiveCompulsive Disorder and Body Dysmorphic Disorder. Leicester (UK): British Psychological Society Copyright (C) 2006, The British Psychological Society \& The Royal College of Psychiatrists.; 2006. [Link]

34. Williams J, Hadjistavropoulos T, Sharpe D. A metaanalysis of psychological and pharmacological treatments for Body Dysmorphic Disorder. Behav Res Ther. 2006;44(1):99-111. Doi: 10.1016/j.brat.2004. 12.006 [Link]

35. Rasing SPA, Creemers DHM, Janssens JMAM, Scholte RHJ. Depression and Anxiety Prevention Based on Cognitive Behavioral Therapy for At-Risk Adolescents: A Meta-Analytic Review. Front Psychol. 2017;8:1066. Doi: 10.3389/fpsyg.2017. 010 66 [Link]

36. Pincus HA, McQueen LE, Elinson L. Subthreshold mental disorders: Nosological and research recommendations. In: Phillips KA, First MB, Pincus HA, editors. Advancing DSM: Dilemmas in psychiatric diagnosis. Arlington, VA, US: American Psychiatric Association; 2003. p. 129-44. [Link]

37. Rodríguez MR, Nuevo R, Chatterji S, Ayuso-Mateos JL. Definitions and factors associated with subthreshold depressive conditions: a systematic review. BMC Psychiatry. 2012;12(1):181. Doi: 10.11 86/1471-244X-12-181 [Link]

38. Haller H, Cramer H, Lauche R, Gass F, Dobos GJ. The prevalence and burden of subthreshold generalized anxiety disorder: a systematic review. BMC psychiatry. 2014;14:128. doi: 10.1186/1471244X-14-128 [Link]

39. Kessler RC, Zhao S, Blazer DG, Swartz M. Prevalence, correlates, and course of minor depression and major depression in the National Comorbidity Survey. J Affect Disord. 1997;45(1-2):19-30. Doi: 10.1016/s0165-0327(97)00056-6 [Link]

40. Flett GL, Vredenburg K, Krames L. The continuity of depression in clinical and nonclinical samples. Psychological Bulletin. 1997;121(3):395-416. Doi: 10.1037/0033-2909.121.3.395 [Link]

41. Littleton HL, Axsom D, Pury CLS. Development of the body image concern inventory. Behaviour 
Research and Therapy. 2005;43(2):229-41. Doi: 10.1016/j.brat.2003.12.006 [Link]

42. Abbasi F, Badami R, Jalali D. The Effect of Mindfulness and Acceptance Training on Body Image Concerns, Mental Skills and Free Throw Shooting Performance in Male Basketball Players with Wheelchairs. Positive Psychology Research. 2018; 4(2):25-40. [Persian]. [Link]

43. Beck AT, Steer RA, Brown GK. Manual for the Beck Depression Inventory-II. San Antonio, TX:: Psychological Corporation; 1996. [Link]

44. Joe S, Woolley ME, Brown GK, GhahramanlouHolloway M, Beck AT. Psychometric properties of the Beck Depression Inventory-II in low-income, African American suicide attempters. J Pers Assess. 2008;90 (5):521-3. Doi: 10.1080/00223890802248919 [Link]
45. Stefan-Dabson K, Mohammadkhani P, MassahChoulabi O. Psychometrics Characteristic of Beck Depression Inventory-II in Patients with Magor Depressive Disorder. USWR. 2007;8(0):82-0. [Persian]. [Link]

46. Beck AT, Kovacs M, Weissman A. Assessment of suicidal intention: The Scale for Suicide Ideation. J Consult Clin Psychol. 1979;47(2):343-52.

47. Anisi J, Fathi Ashtiani A, Salimi SH, Ahmadi Noudeh K. Validity and Reliability of Beck Suicide Scale among Soldiers. Journal of Military Medicine. 2005;7(1):33-7. [Persian]. [Link] 